\title{
Plant Tissue Decay in Long-Term Experiments with Microbial Mats
}

\author{
Miguel Iniesto ${ }^{1,2}, * \mathbb{}$, Candela Blanco-Moreno ${ }^{3}$, Aurora Villalba ${ }^{2}$, Ángela D. Buscalioni ${ }^{3}$, \\ M. Carmen Guerrero ${ }^{2}$ and Ana Isabel López-Archilla ${ }^{2}$ \\ 1 Diversity, Ecology and Evolution of Microbes Laboratory, Ecologie Systématique Evolution, CNRS, \\ Université Paris-Sud, 91405 Orsay, France \\ 2 Department of Ecology, Universidad Autónoma de Madrid, 28049 Madrid, Spain; \\ aurora.villalba@estudiante.uam.es (A.V.); mcgs210@hotmail.com (M.C.G.); anabel.lopez@uam.es (A.I.L.-A.) \\ 3 Department of Biology, Universidad Autónoma de Madrid, 28049 Madrid, Spain; \\ candela.blanco@uam.es (C.B.-M.); angela.delgado@uam.es (A.D.B.) \\ * Correspondence: miguel.iniesto@gmail.com; Tel.: +33-768-88-51-53
}

Received: 30 August 2018; Accepted: 19 October 2018; Published: 25 October 2018

\begin{abstract}
The sequence of decay in fern pinnules was tracked using the species Davallia canariensis. Taphonomic alterations in the sediment-water interface (control tanks) and in subaqueous conditions with microbial mats were compared. The decay sequences were similar in control and mat tanks; in both cases, pinnules preserved the shape throughout the four-month experience. However, the quality and integrity of tissues were greater in mats. In control tanks, in which we detected anoxic and neutral acid conditions, the appearance of a fungal-bacterial biofilm promoted mechanical (cell breakage and tissue distortions) and geochemical changes (infrequent mineralizations) on the external and internal pinnule tissues. In mats, characterized by stable dissolved oxygen and basic $\mathrm{pH}$, pinnules became progressively entombed. These settings, together with the products derived from mat metabolisms (exopolymeric substances, proteins, and rich-Ca nucleation), promoted the integrity of external and internal tissues, and favored massive and diverse mineralization processes. The experience validates that the patterns of taphonomic alterations may be applied in fossil plants.
\end{abstract}

Keywords: experimental taphonomy; plant fossilization; soft-tissue preservation; plant decay; biomineralization

\section{Introduction}

Fossilization is a very complex process involving the pull of modifications that occur before and/or after burial (i.e., biostratinomy and diagenesis, respectively) [1]. Although it is uncommon, certain microenvironments may enhance preservation, allowing the formation of Konservat-Laggerstätten (KL) [2]. According to their palaeobiological information, they can be considered actual windows to the past. KL are frequently interpreted as the result of the combination of very particular palaeoecological and/or palaeoenvironmental factors [3]. This local concentration of exceptional fossils provides remarkable information to aid in the understanding of the ancient Earth. In addition, the state of preservation of fossils from KL is characterized by the conservation of soft tissues, even at the subcellular level [4-8], providing a more complete view of ancient anatomies and diversity patterns.

The characterization of the fossil records provides essential information about macroevolution and taphonomic processes [9-14]. Nonetheless, intensive observations and analysis of the fossil record should be complemented by taphonomic experiments. In fact, experiments in taphonomy have an increasing importance in palaeontological investigations. This kind of experiment provides the necessary information to describe the relevant taphopathways that are involved in the exceptional 
preservation of organic tissues such as (1) the consequence of cell autolysis within tissues [15-17]; (2) the discriminatory mineralization of tissues [18-22]; (3) the action of diagenesis (e.g., temperature and/or pressure) [23-28]; and (4) the impact of microbial communities and the potential interactions with decaying bodies [14,29-35]. In addition, in the case of plants, other taphonomic pathways, e.g., coal-ball formation [36,37] or charcoalification [38-40], have also been proven to be relevant (for more details on plan taphonomy, see Locatelli [41]). However, there are many aspects of these processes that remain unknown so far. For example, experiments with microbial communities have mainly focused on the preservation of animals [31,42-45]. Consequently, the knowledge of the impact of microorganisms in the decay of plants is scarce, and is commonly based on monitoring the deterioration of leaves from the natural process of microbial decomposition (e.g., Gupta et al. or Locatelli $[24,46,47])$.

The present study reports the first experiment to record the sequence of modifications of plant tissues during their decomposition in a complex microbial community that is known as a microbial mat. Consequently, this experiment tries to complement previous approaches by using simple biofilms $[35,48]$. Contrasting with simple biofilms, which have a low complexity, microbial mats are stratified organo-sedimentary structures with high diversity $[49,50]$ and a great degree of consistency. Based on the inherent properties of mats, some authors believe that these communities could play a key role in fossilization [51-54]. Previous experiments with animal carcasses have shown that the growth of the upper layers of mats over bodies promotes the generation of a conservative sarcophagus [14,31]. This sarcophagus is linked with fossilization in different ways, namely: (1) promoting the formation of impressions and replicas at the carcass-mat interface [34,55]; (2) favoring the lithification of carcasses [33]; and (3) controlling the microenvironment in which fossilization takes place [32]. In the case of plant fossilization, recent experiments [35] have contributed to the knowledge of the formation of leaf adpressions (i.e., a style that encompasses a spectrum of plant fossil compressions [56,57]) through the biofilm-clay model in which biotic and abiotic factors influence the fossilization of plants. The aim of the present paper is to establish whether the potential for the exceptional preservation in mats also applies to vegetal tissues.

\section{Material and Methods}

\subsection{Preparation of Microbial Mats in the Laboratory}

Microbial mat samples were collected at Lake Salada de Chiprana (Zaragoza, Spain) in the semi-arid region of the Ebro depression (Aragon, NE Spain) (Figure 1A,B). This lake, which has an endorheic origin, is hypersaline (30-70\%), resulting from the influx of ground water from a source that is rich in magnesium sulphate (up to 700 meq. $\mathrm{L}^{-1}$ of $\mathrm{SO}_{4}{ }^{2-}$ and $\mathrm{Mg}^{2+}$ ) and sodium chloride (approximately $300 \mathrm{meq} \cdot \mathrm{L}^{-1}$ ) [58]. 

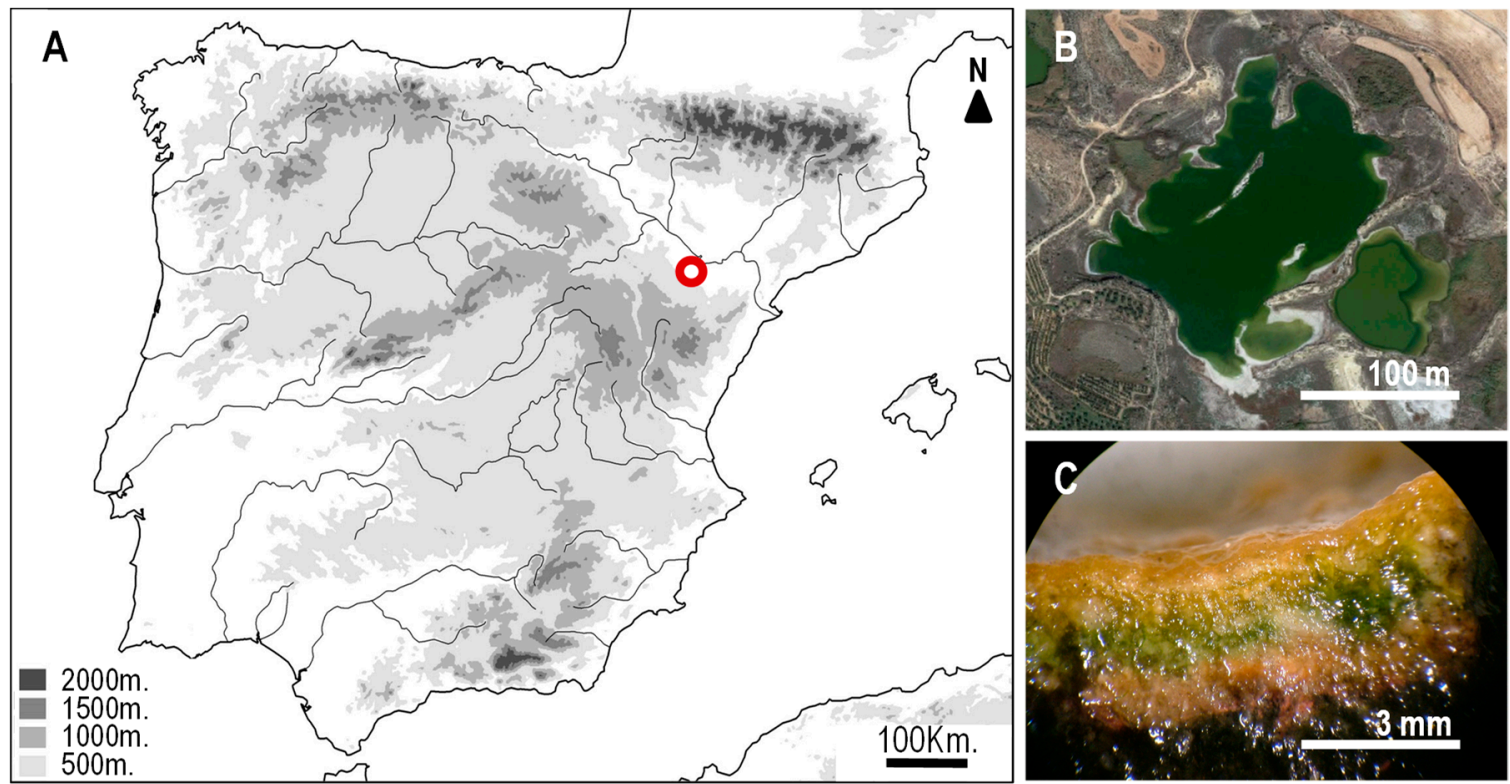

Figure 1. (A) Map showing the location of the Lake Salada de Chiprana (Zaragoza, Spain) (red spot) in the semi-arid region of the Ebro depression (Aragon, NE Spain). (B) Satellite view of the lake (Google Earth). (C) Section of the microbial mat from the Salada de Chiprana showing the multilayered organization. Although it is impossible to determine the exact composition of fossil mats, cyanobacterial photosynthetic mats (as those assumed to be present in past ecosystems) have common features $[59,60]$ that allow the assumption that recent mats are a good analog.

Chiprana mats were crushed and prepared as described in previous experiments [31,32] and placed in three $30 \times 15 \times 17 \mathrm{~cm}$ glass tanks (T1 to T3) containing a 2-3 cm base of limestone, overlain by a 3-4 cm layer of sediment from the lake. Tanks were filled with water from the lake until a 2-cm water column was obtained over the surface of the crushed mat or sediment (see Iniesto et al. [33] for more details on water composition). After this preparation, microbial mats were grown in the laboratory until maturation, i.e., when the mats exhibited the characteristic multilayered organization and pinnacles (Figure 1C). Chambers were illuminated with a cold beam (OSRAM Decostar 51 Titan) with a photoperiod similar to the natural one (adjusted to $10 \mathrm{~h}$ of daylight). One additional tank was prepared with the same protocol, but lacked a microbial mat to be used as a control (Cs). The control tank was kept in the dark to prevent the development of a mat from the resting stages of photosynthetic populations in the sediment. During the course of the experiment, tanks were kept in a controlled-temperature room (water temperature was $23 \pm 0.5^{\circ} \mathrm{C}$ ). The water depth (about $2 \mathrm{~cm}$ ) was almost constant in the tanks due to the periodical input of sterilized distilled water to compensate for water evaporation.

\subsection{Taphonomic Experiments}

The experiment was conducted using the fern Davallia canariensis (L.) Sm. as the plant model. We distributed 12 pinna fragments $(\sim 1.5 \mathrm{~cm})$ over the surface of the tanks, with gaps of $2.5 \mathrm{~cm}$. All of the pinna were placed with the lower surface (abaxial) in contact with the microbial mat. Fragments were analyzed at random (one per tank) on days $0,7,15,30,60$, and 120 . Several physico-chemical variables were measured to document their possible variations over the course of the experiment: dissolved oxygen (DO), conductivity, and $\mathrm{pH}$ were measured with specific probes (WTW Oxi 315i/Set 2C10-0011, WTW Cond 315i 2C10-0011 and Crison pH-meter Basic 20 respectively). The ionic composition of the water was determined at each experimental time by ionic chromatography (SiDI, Universidad Autónoma de Madrid, Spain). 


\subsection{Sample Preparation and Analytical Procedure}

At earlier sampling times, before the pinnules had been overgrown by the mats, each fragment was prepared for sampling by carefully removing it from the surface of the mat. At later sampling time points, after the pinna had been covered by the upper layers, we used a scalpel to remove and prepare each fragment. Afterwards, the plants' remains were washed with distilled water in order to remove sediment particles and fixed in methanol in a vacuum chamber for $20 \mathrm{~min}$. Then, the fragments were subdivided into three parts and processed in parallel for different microscopic observations. Thin sections were prepared using a rotary microtome. These sections were later examined under a Clear-Field Optic Microscope to observe the decay in the plant tissues, and by inverted fluorescence microscopy to monitor the possible presence of calcium bioprecipitates. Scanning electron microscopy (SEM) was used to observe the deterioration of the surface of the pinnules. Potential precipitates were identified using energy dispersive X-ray spectroscopy (EDXS) (samples without resin); the deterioration of the internal tissues was observed through cross-sections of the pinnule (samples embedded in Spurr resin) (see below).

\subsubsection{Fluorescence Microscopy}

One fragment was stained with calceine at $1 \%$ (this substance is used for the fluorometric determination of calcium) and DAPI (4',6-diamidino-2-phenylindole) at $10 \%$ (a fluorescent stain that binds strongly to DNA, which allowed us to locate the cells in the sample) prior to dehydration as follows: (1) calceine solution was prepared (10-mL Tris buffer, 104- $\mu \mathrm{L}$ DMSO, and 1-mg calceine SIGMA-ALDRICH CO875-5G), (2) DAPI was prepared (4-mL Tris Buffer, 2- $\mu$ L DAPI SIGMA-ALDRICH D9542-SMG), (3) the sample was immersed in the calceine solution $\left(48 \mathrm{~h}, 4{ }^{\circ} \mathrm{C}\right.$, obscurity) and (4) staining with DAPI occurred (12 h, $4{ }^{\circ} \mathrm{C}$, obscurity). Afterwards, the sample was dehydrated using ethanol at increasing concentrations $(30 \%, 70 \%, 3 \times 100 \%, 20$ min each step, final step $45 \mathrm{~min}$ ). Samples were embedded in paraffin as follows: (1) ethanol-xylene 1:1 (45 min), (2) xylene 100\% ( $2 \times 45 \mathrm{~min}$.), (3) xylene-paraffin 1:1 (90 min.), (4) paraffin (PANREAC, Barcelona, Spain) infiltration $\left(2 \times 45 \mathrm{~min}\right.$.), and (5) the polymerization of paraffin (overnight, $60{ }^{\circ} \mathrm{C}$ ). Liquid paraffin was prepared by heating the solid fragments up to $50.5^{\circ} \mathrm{C}$. Later, a resin block was trimmed in 5-10 $\mu \mathrm{m}$ sections using a microtome (LEICA RM2245, Leica Microsystems AG, Wetzlar, Germany). Slides with paraffin were placed in a vessel and incubated in a $60^{\circ} \mathrm{C}$ oven for $45 \mathrm{~min}$ (so the wax just started to melt). The dewaxing slides were then submerged in xylene $(3 \times 5 \mathrm{~min}$.) and finally attached to the glass slide with Prolong (Thermo Fisher Scientific P36961, Thermo Fisher Scientific, Waltham, USA). Observations were performed using an Olympus Reflected Fluorescence System CKX41 (Olympus, Tokyo, Japan) coupled with two filters: $515 \mathrm{~nm}$ (calceine) and $461 \mathrm{~nm}$ (DAPI).

\subsubsection{SEM-EDX and Resin Inclusion}

Two fragments of each pinnule were dehydrated after their fixation in methanol using ethanol at increasing concentrations (30\%, 70\%, 3 $\times 100 \%, 20$ min each step, final step $45 \mathrm{~min})$. Afterwards, one of the fragments was fixed using glutaraldehyde (2.5\%) and dried in a dark and dry chamber at room temperature until observation with SEM. The second fragment was directly transferred from the final $100 \%$ ethanol to the process of inclusion in Spurr resin as follows: (1) acetone (15 min.), (2) acetone-Spurr mix (1:1; 30 min.), (3) acetone-Spurr mix (1:2; 12 h.), (4) Spurr 100\% (2 h), and (5) inclusion in Spurr using silicone molds $\left(24 \mathrm{~h}, 60^{\circ} \mathrm{C}\right)$. Once completely polymerized, the resin block was polished with diamonds down to $0.75 \mu \mathrm{m}$ in size.

Prior to observation, samples were coated with gold. Images and analyses were collected in backscattered and secondary electron modes using a Hitachi S3000N (Hitachi, Chiyoda, Japan) operating at $15 \mathrm{kV}$, with a 60 - $\mu \mathrm{m}$ aperture at a working distance of approximately $15 \mathrm{~mm}$. Elemental compositions were determined using energy dispersive X-ray spectrometry (EDXS) with an Oxford Instruments INCAx-sight system (Oxford Instruments, Abingdon, UK). 


\section{Results}

\subsection{Physico-Chemical and Ionic Variations in the Course of the Decay of Pinnae in Mats}

Dissolved oxygen (DO) showed important variations during the course of the experiment (Figure 2A) and differed between tanks with mats and the control tank. While the controls almost reached anoxic conditions, tanks with mats had an average concentration of $9.8 \mathrm{mg} / \mathrm{L}$ during the experiment. The maximum values in mat tanks were recorded at days 30 and 53, with $16.5 \mathrm{mg} / \mathrm{L}$ and $16.0 \mathrm{mg} / \mathrm{L}$, respectively. We also detected remarkable variations between sampling days up to $10 \mathrm{mg} / \mathrm{L}$ in day 44 . From day 80 , the DO showed very similar values in the three tanks with mats, and became relatively constant.

Tanks with and without mats also showed differences in $\mathrm{pH}$. Values in the controls were stable, ranging between 7.8 and 8.4. As in the case of $\mathrm{DO}$, tanks with mats also showed more variation over time than the controls. The $\mathrm{pH}$ was considerably more basic in mats than in the control at time 0 . Nonetheless, during the course of the experiment, they exerted a decrease in $\mathrm{pH}$ down to values that were very similar to those of the control tank (Figure 2B).
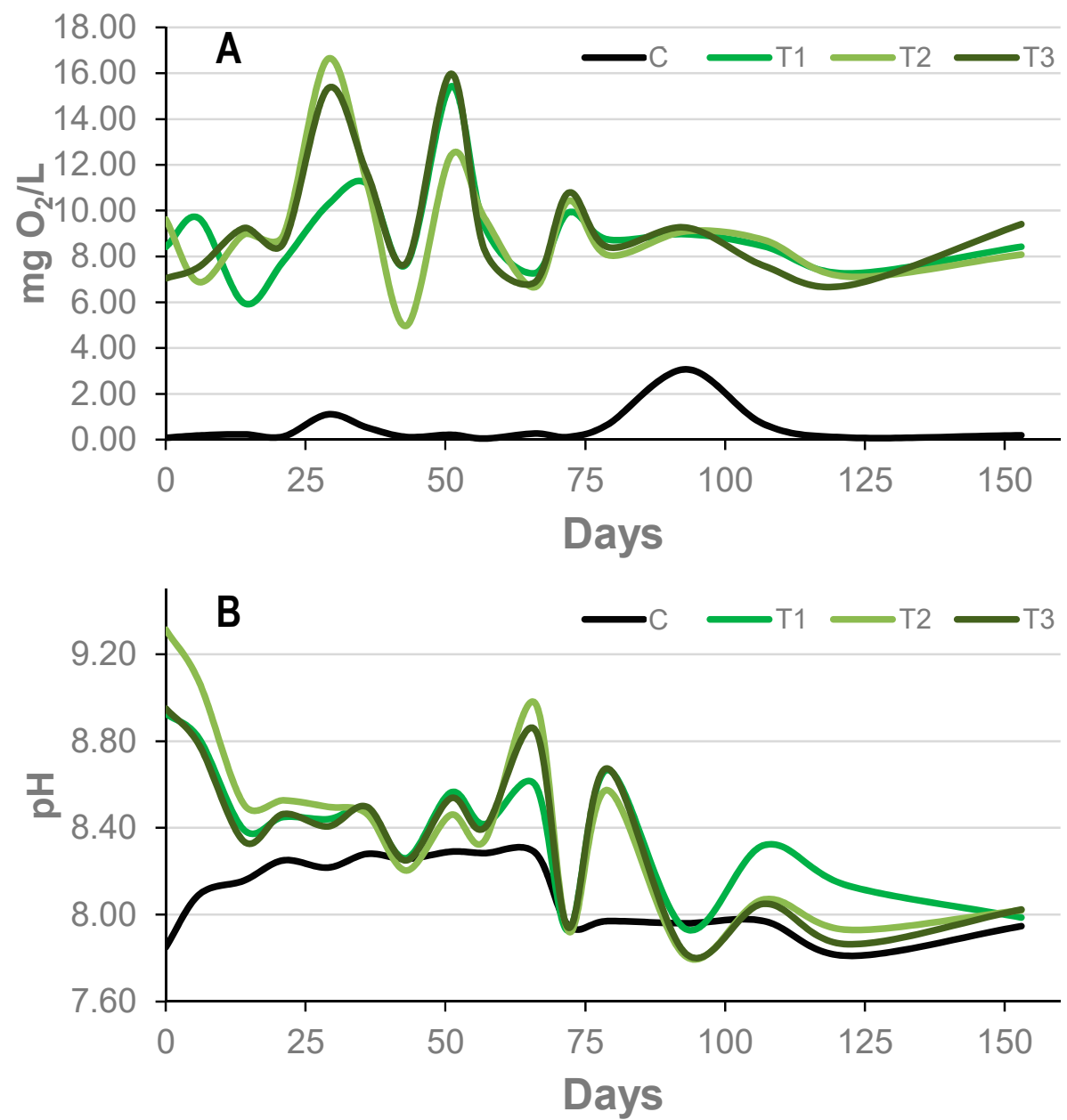

Figure 2. Evolution of dissolved oxygen (DO) (A) and $\mathrm{pH}(\mathbf{B})$ in the water column in the tanks with mats (T1-3, green lines) and in the control (C, black line) in the course of the experiment.

Conductivity and temperature are not as affected by biological activity as $\mathrm{pH}$ or DO. However, in order to get reliable results, it is necessary to control them and keep them constant. The conductivity of the tanks with mats was similar over time $\left(59.1 \pm 1.1 \mathrm{mS} \cdot \mathrm{cm}^{-1}\right)$. However, the control tank (without a mat) showed a higher conductivity over the entire experimental period $\left(75.8 \pm 6.9 \mathrm{mS} \cdot \mathrm{cm}^{-1}\right)$. It was easier to keep the temperature constant in the controlled room, with very similar values 
shown between the tanks with mats $\left(22.8 \pm 0.8^{\circ} \mathrm{C}\right)$, although the control tank had a slightly higher temperature $\left(23.1 \pm 0.7^{\circ} \mathrm{C}\right)$ because it was covered to prevent the entry of light.

The main water anion in the tanks was sulfate, followed by chlorine, while sodium and magnesium were the predominant cations, which is consistent with the original water composition. Calcium, potassium, and ammonium were also present. In contrast, the ionic composition varied less during the experiment, although the control tank always had a higher ionic concentration than the tanks with mats (as could be deduced from the conductivity values). The initial concentrations were always the highest, while at 15 days, the lowest concentrations were measured (Table 1).

Table 1. Evolution of the ionic water composition (ppm) in controls (C) and microbial mat (T1 and T2) tanks.

\begin{tabular}{cccccccc}
\hline ppm & $\mathbf{C l}^{-}$ & $\mathbf{S O}_{\mathbf{4}}{ }^{\mathbf{2}}$ & $\mathbf{N a}^{+}$ & $\mathbf{N H}_{\mathbf{4}}{ }^{+}$ & $\mathbf{K}^{+}$ & $\mathbf{M g}^{2+}$ & $\mathbf{C a}^{\mathbf{2 +}}$ \\
\hline T1 T0 & 27,827 & 79,684 & 18,418 & 261 & 646 & 17,613 & 768 \\
T1 T15 & 15,750 & 30,779 & 9371 & 138 & 298 & 7221 & 438 \\
T1 T30 & 20,314 & 48,657 & 13,785 & 231 & 456 & 11,516 & 655 \\
T1 T60 & 21,042 & 52,047 & 13,019 & 256 & 454 & 10,475 & 691 \\
T2 T0 & 27,827 & 79,684 & 18,418 & 261 & 646 & 17,613 & 768 \\
T2 T15 & 20,831 & 46,376 & 13,192 & 219 & 294 & 10,500 & 581 \\
T2 T30 & 21,098 & 46,891 & 13,204 & 208 & 300 & 10,604 & 597 \\
T2 T60 & 21,455 & 48,446 & 12,894 & 695 & 316 & 10,499 & 610 \\
C T0 & 27,827 & 79,684 & 18,418 & 261 & 646 & 17,613 & 768 \\
C T15 & 24,883 & 66,360 & 16,863 & 358 & 492 & 15,317 & 775 \\
C T30 & 26,308 & 72,169 & 17,441 & 399 & 496 & 16,177 & 769 \\
C T60 & 23,847 & 60,901 & 15,454 & 401 & 506 & 13,579 & 669 \\
\hline
\end{tabular}

\subsection{Decay of Fern Pinnae}

The decay of pinnae was monitored de visu with clear-field optic microscopy, fluorescent microscopy, and SEM in order to detect the potential influence of the mats. However, the direct observation of samples in mats was only possible during the first few days, because of the coverage of pinna by the microbial mat.

\subsubsection{Formation of the Sarcophagus}

The reorganization of the upper layers of the mats was intense from the very start of the experiment. Several pinnae were already trapped by the microbial mat after only four days, and after two weeks, all of the leaflets were completely covered (Figure 3A-E). Moreover, after extracting the pinna from the mat at day 7 , we observed a precise impression of the outline of the pinnules on the surface of the mat (Figure 3G).

\subsubsection{Sequence of Decomposition of Fern Pinnae}

We detected a gradual variation in color in all of the samples. Samples with mats and controls turned darker over the course of the experiment. However, this shift was more intense in the controls, even when the overall condition of controls seemed to be good. 

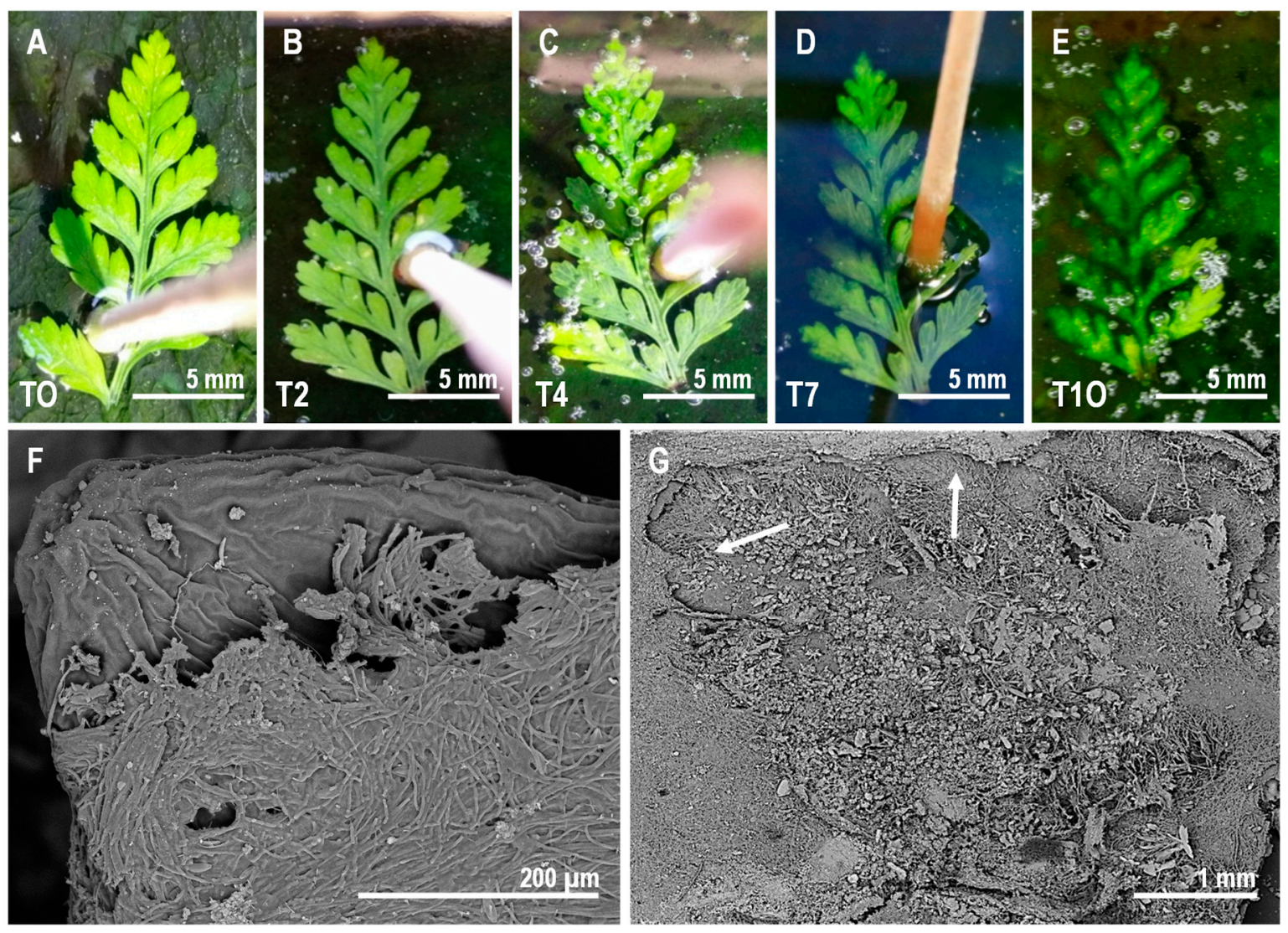

Figure 3. Sequence of coverage of the pinna by the microbial mat over the course of the experiment. (A-E) Gradual initial phase of coverage from day 0 (T0, A) to day 10 (T10, E). (F) SEM observations of the microbial veil covering the pinna. (G) Impression of the lower side of the fern pinna left on the surface of the mat after its removal at day 7 . The shape of the fern in the mat is highlighted by two white arrows.

The distinct tissue structures of the thin section of Davallia pinna were identified (Figure 4) and observed throughout the course of the experiments to test their transformations over time. The sections were observed by an optic microscope with bright light (Figure 5) and fluorescence (Figure 6) to determine the effect of decay at the tissue level. In contrast to the few observed differences de visu between treatments (with and without a mat), the observation of sections performed in the control samples revealed an evident decay of tissues. The decay affected the lower epidermis in the control material as early as day 7 (Figures 5D and 6D), when broken cell walls could already be observed. The fern pinnules in the microbial mats were more compressed, but had intact epidermises at day 7 (Figure 5I,J and Figure 6I,J). At day 30, the control material showed damage in the endodermis (Figure 5F), deformed cells in the mesophyll, and extensive damage in the lower epidermis (Figure 6E,F). At this time, the samples in the mats only started to show broken lower epidermis cell walls (Figure 5L). Finally, at day 120, the control material had fungal infections at the vascular area (Figure 5H), and the cells of the upper and lower epidermis were separated from each other, forming gaps through which water entered, dispersing the cells of the mesophyll (Figure 5G,H). In contrast, the pinnules that were embedded in the microbial mats only showed some deformed cells in the mesophyll and light damage in the endodermis (Figure 5M,N). 


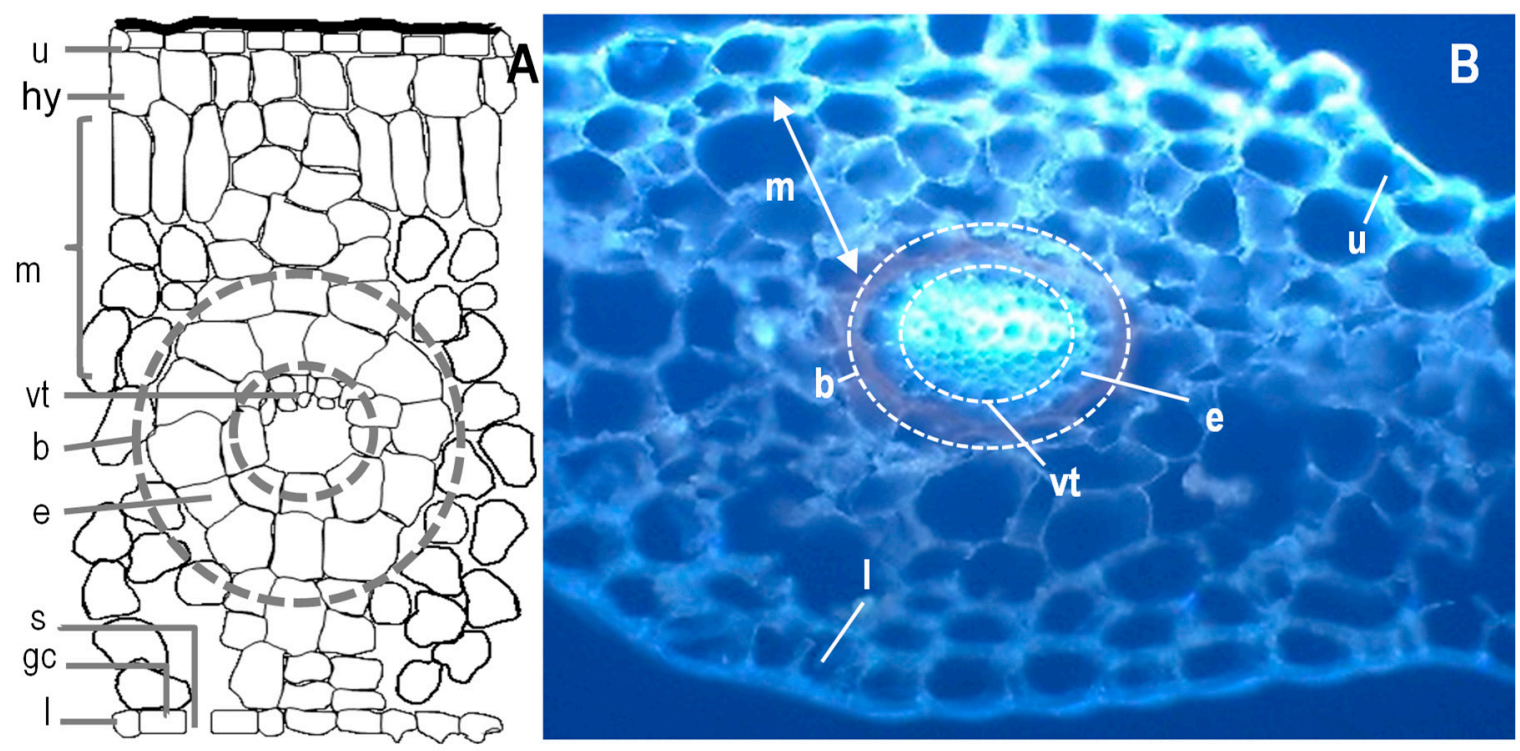

Figure 4. (A) Scheme of the histology of fern and thin sections of a pinna observed using fluorescence optic microscopy of Davallia canariensis (B). Abbreviations: (u) upper epidermis, (hy) hypoderm, (m) mesophyll, (vt) vascular tissues, (e) endodermis, (b) bundle sheath, (l) lower epidermis, (s) stoma and (gc) guard cell. Based on Reihman and Schabilion [61].
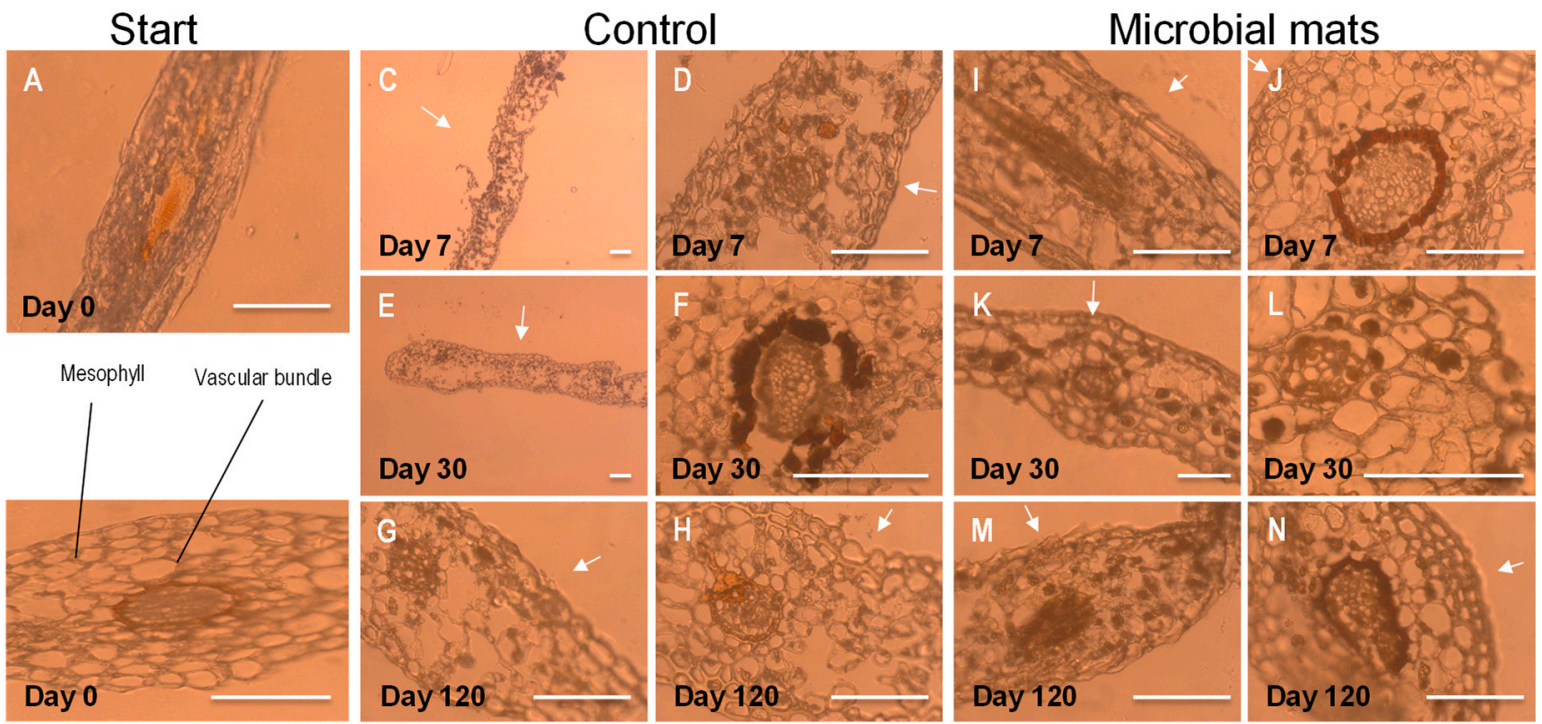

Figure 5. Observation of thin sections of pinna at the beginning of the experiment using a Clear-Field Optic Microscope (A,B) and the evolution of controls at days 7, 30, and $120(\mathbf{C}-\mathbf{H})$ and samples from tanks with microbial mats $(\mathbf{I}-\mathbf{N})$. The white arrows point to the upper side of the pinna. Scale bar: $200 \mu \mathrm{m}$. 

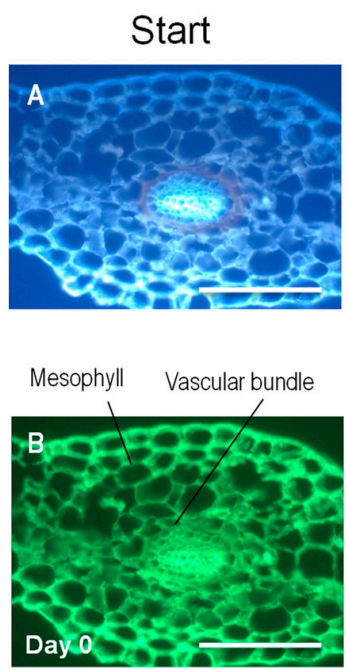
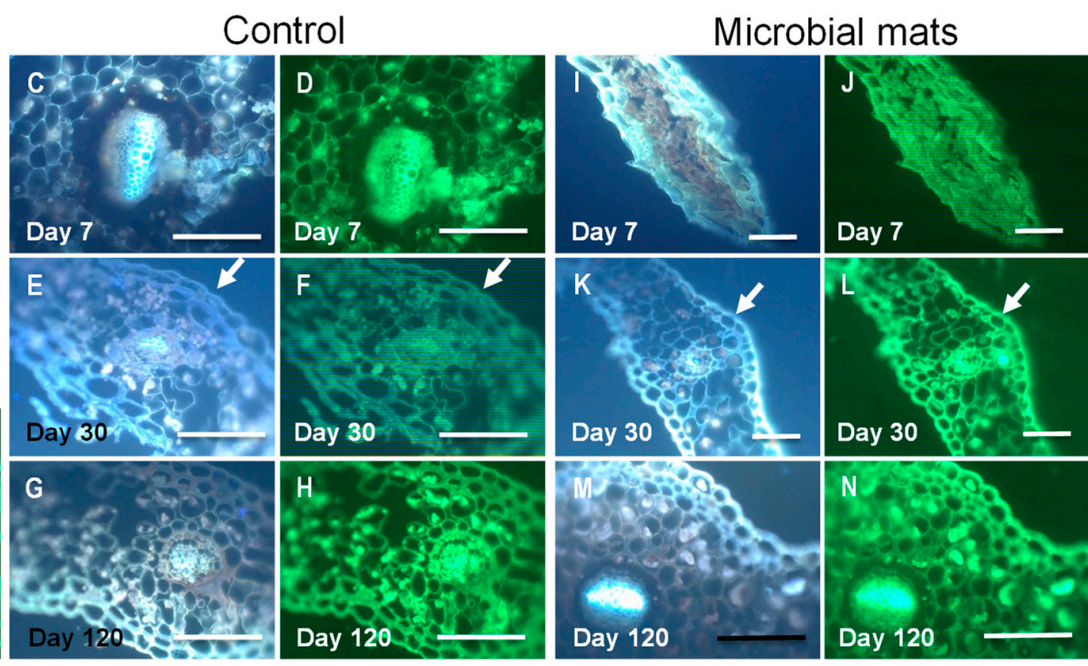

Figure 6. Observation of thin sections of pinna using a fluorescence microscope. Samples were stained with DAPI (blue) and calceine (green). (A,B): Plant tissues at the beginning of the experiment. (C-H): Evolution of decay of ferns from day 7 until day 120. (I-N): Observations of pinna in mats at days $7(\mathbf{I}, \mathbf{J}), 30(\mathbf{K}, \mathbf{L})$, and $120(\mathbf{M}, \mathbf{N})$. The arrows in $(\mathbf{E}, \mathbf{F}, \mathbf{K}, \mathbf{L})$ point to the cuticle that was more damaged in the controls than in the mats.

The upper side of the pinna samples, which was observed using SEM (Figure 7), showed that, in contrast to the tissue thin sections, the controls did not show much external decay. Starting at day 30 , we detected the presence of several filaments, which were likely fungi, on the surface (Figure 7B). After day 60, a mucous veil trapping of sediment particles was detected in several areas of the surface (Figure 7C). A cross-section of the pinna showed the presence of fungal filaments inside the tissue (Figure 7D). In the case of samples over the mats, the upper cover of the sarcophagus was mainly formed by diatoms and filamentous cyanobacteria (Figure 7E). This cover became denser and increased its mucus composition over time (Figure 7F). The presence of microorganisms invading the internal tissues was not detected (Figure 7G), which was in contrast with controls.
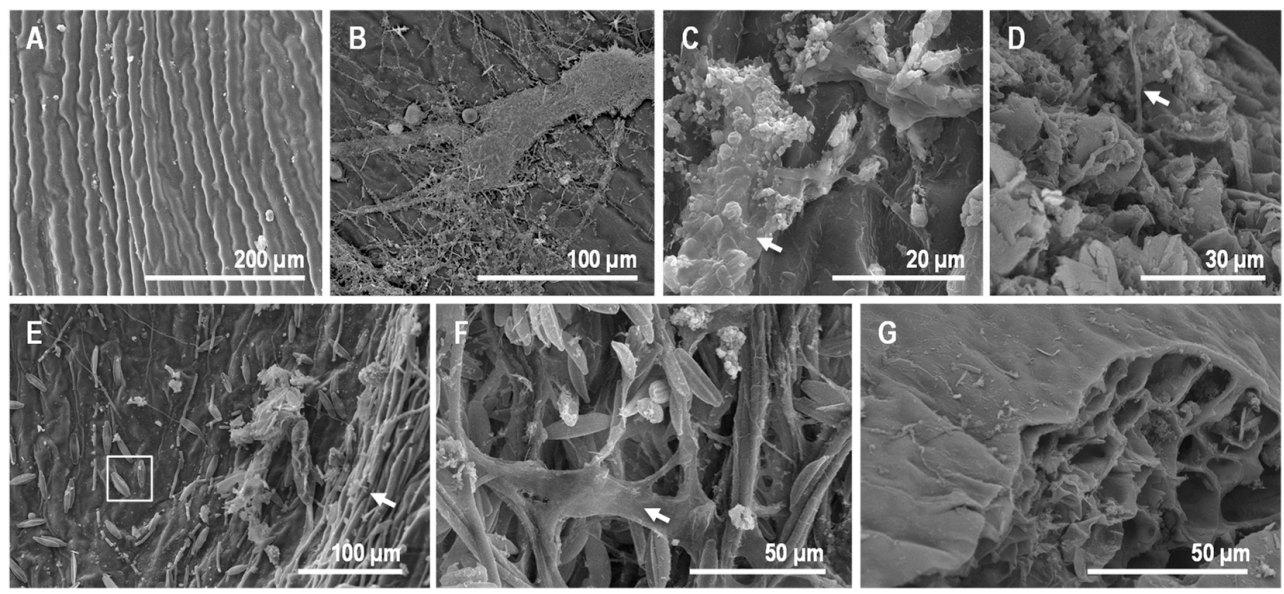

Figure 7. Observations of fern pinna using SEM. (A) External view of the upper side of the sample at day 0. (B) Control at day 30, with the top (upper surface) partially covered by fungi filaments. (C) At day 60, controls showed abundant extracellular polymeric substances (EPS) covering the surface. This EPS trapped some sediment particles (arrow). (D) The transverse section of the control at day 60 exposed fungi filaments inside the fern tissues (arrow). (E) Some cyanobacterial filaments (arrow) and diatoms (dotted round) at day 7 on the upper side of the fern frond in mats. (F) Fern in mat at day 60, with cyanobacteria and diatoms trapped by EPS (arrow). (G) Tissue section of the pinna at day 60, free of microorganisms within cells. 


\subsubsection{Plant Tissue Mineralization and the Occurrence of Mineral Precipitates}

In controls, the occurrence of precipitates was infrequent but noticeable from the beginning (Figure 8A). At days 7 and 15, the presence of an organic veil rich in minerals (e.g., $\mathrm{Ca}, \mathrm{Mg}, \mathrm{P}, \mathrm{Na}$; Figure $8 \mathrm{~B}$ ) was detected. This mineral composition was consistent with the water from the Salada de Chiprana that was used in the experiment (Table 1 and Iniesto et al. [33]). In contrast, the surface of the fern was enriched in S, but $\mathrm{P}$ was absent (Figure 8C). At day 30, spherical precipitates with a diameter of $\sim 10 \mu \mathrm{m}$ (Figure 8D) that were rich in $\mathrm{Cl}, \mathrm{Mg}, \mathrm{S}$, and $\mathrm{Na}$ (Figure $8 \mathrm{E}$ ) were produced. In particular, the biofilm formed by the fungal mass had a similar composition, but was enriched in $\mathrm{P}$ and S (Figure 8F). After day 60, the precipitation of gypsum was identified (Figure 8H,I), occurring even in the internal tissues of the pinna (Figure 8J,K).
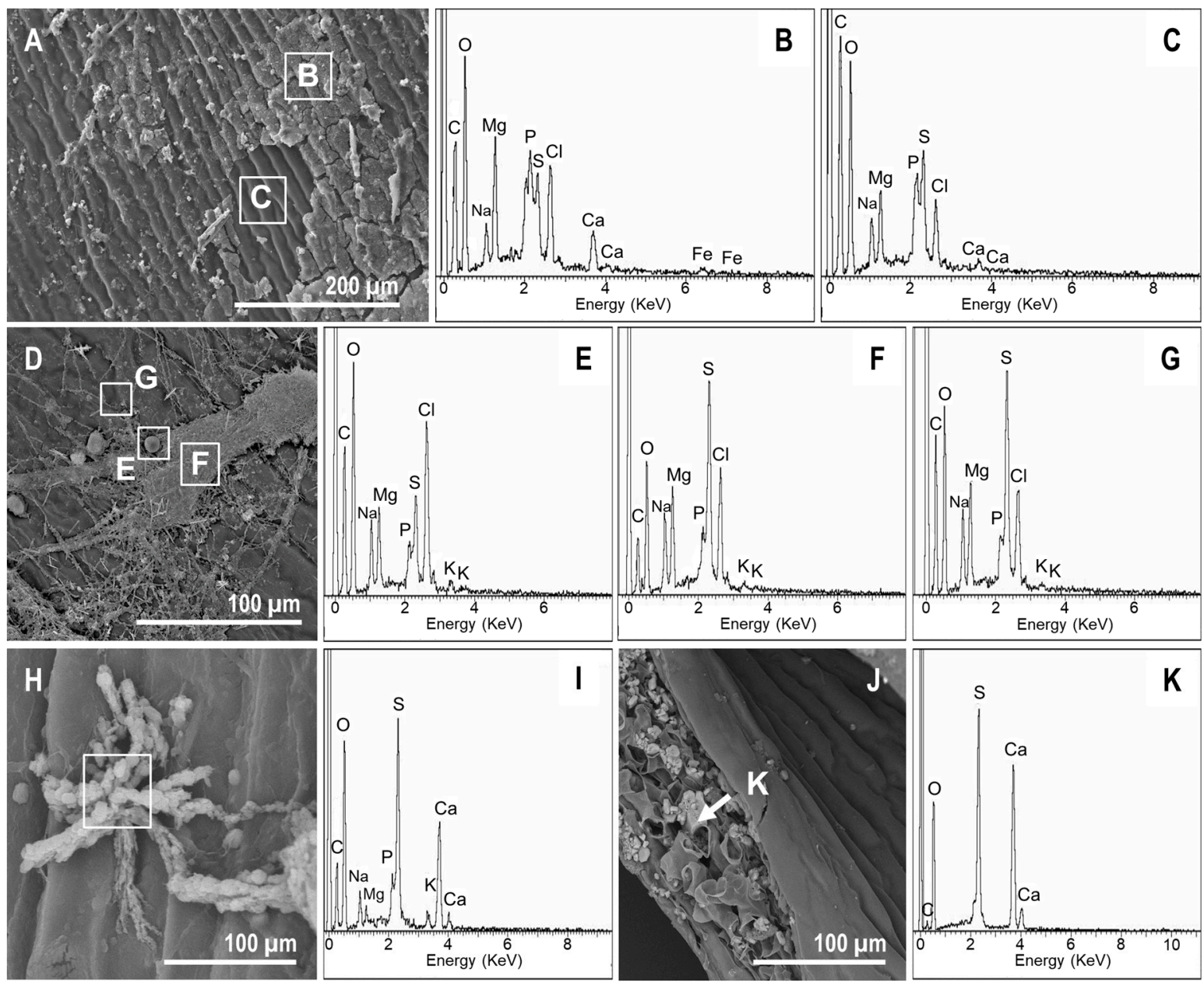

Figure 8. SEM-energy dispersive X-ray spectroscopy (EDXS) images and analyses of mineral precipitates in controls. (A) Organic veil covering the surface of the fern at day 7. (B,C) Elemental composition of the veil (enriched in $\mathrm{Mg}, \mathrm{P}, \mathrm{Ca}$, and $\mathrm{Cl}$ ) and the upper side of the pinna, respectively. (D) At day 30, the upper side of the pinna was still covered by the organic mucilaginous veil. Moreover, spherical precipitates with diameters of $\sim 10 \mu \mathrm{m}$ were detected. Three different points were analyzed (highlighted with dotted rounds): (E), spherical precipitates; (F), organic veil, and (G), fern surface. (E) Elemental composition of the spherical precipitates that were rich in $\mathrm{Cl}, \mathrm{Mg}, \mathrm{S}$, and $\mathrm{Na}$. (F) The biofilm formed by the fungi had a similar composition, but presented more $\mathrm{P}$ and a depletion of $\mathrm{S}$. (G) The surface composition was consistent with the analysis at day 7, but Ca seemed to be absent. (H) Observations at day 60. Star-shaped precipitates that were rich in S and Ca. (I) appeared on the upper side of the sample. (J) At day 60, the occurrence of precipitates enriched in S and $\mathrm{Ca}(\mathbf{K})$ within the leaf was detected. 
In mat tanks, the precipitates also appeared quickly. However, in contrast to the controls, precipitates had a widespread distribution with a high variety of elemental compositions. Ca-rich precipitates were observed on the upper side starting at day 7 (Figure 9A,B). The organic veil excreted by the microorganisms of the mat contained large amounts of $\mathrm{S}, \mathrm{Mg}, \mathrm{Na}, \mathrm{P}$, and $\mathrm{Cl}$, and lower concentrations of $\mathrm{Si}, \mathrm{K}$, and $\mathrm{Ca}$ (Figure 9A,C). In addition to these Ca-rich precipitates, gypsum-like minerals were also detected on the surface of the mat (Figure 9D,E). The impression of the lower side of the pinna that was detected on the surface of the mat (Figure 3G) contained numerous precipitates with different morphologies (i.e., starred, spherical, conglomerates, and rod-shaped precipitates, Figure 9D,F). Despite their morphological differences, some of them (e.g., starred and spherical particles) had similar compositions (Figure 9F,H). According to their elemental compositions and morphologies, they were consistent with gypsum and carbonate precipitates, and they were stable and evident at day 60 (Figure 9I-M). Additionally, at day 30, several spots covered by a mucilaginous layer filling the space between the cells of the microbial P-enriched biofilm (Figure 10A,B) were detected in one of the tanks. However, this veil vanished at day 60 (Figure 1C).
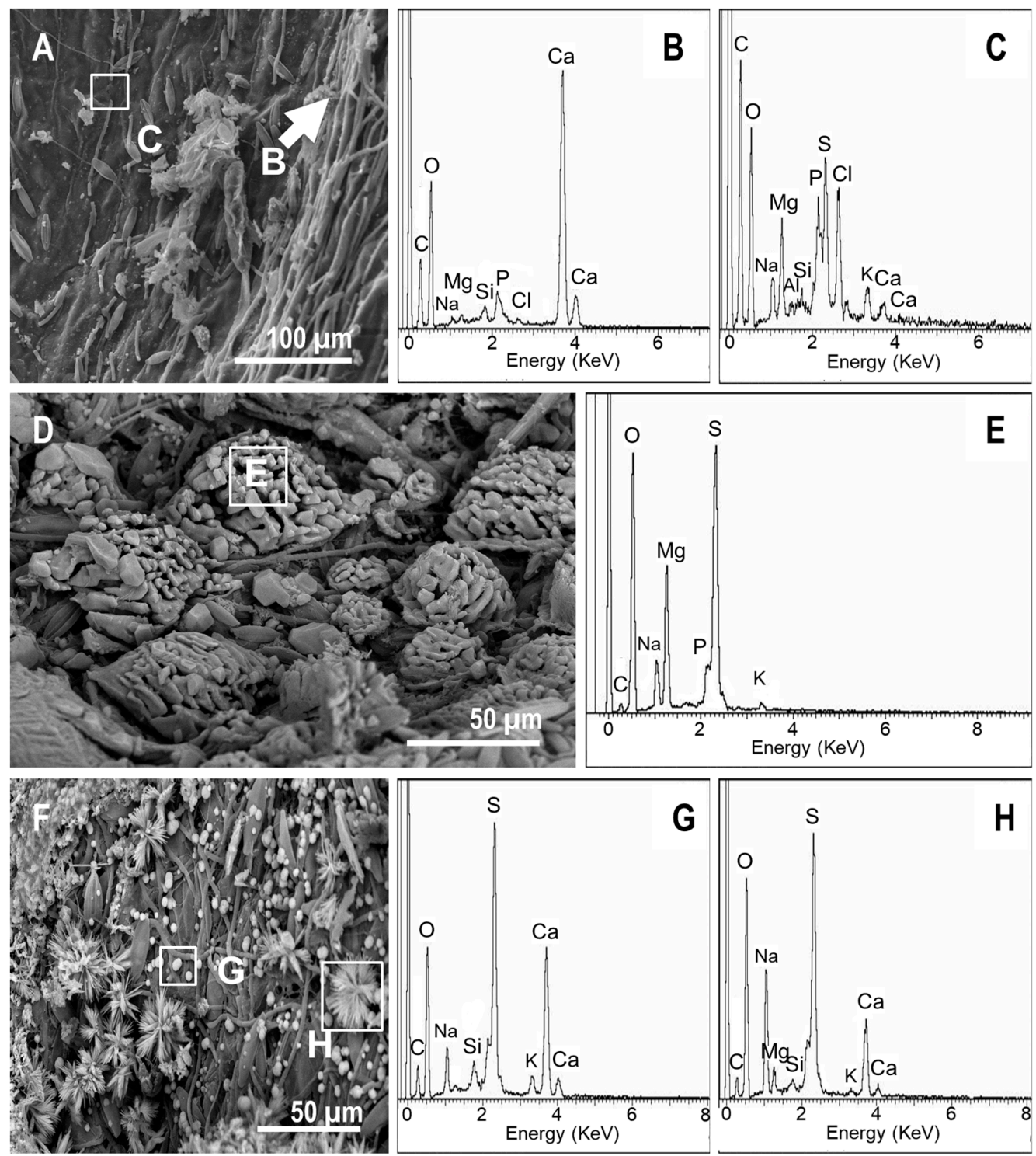

Figure 9. Cont. 

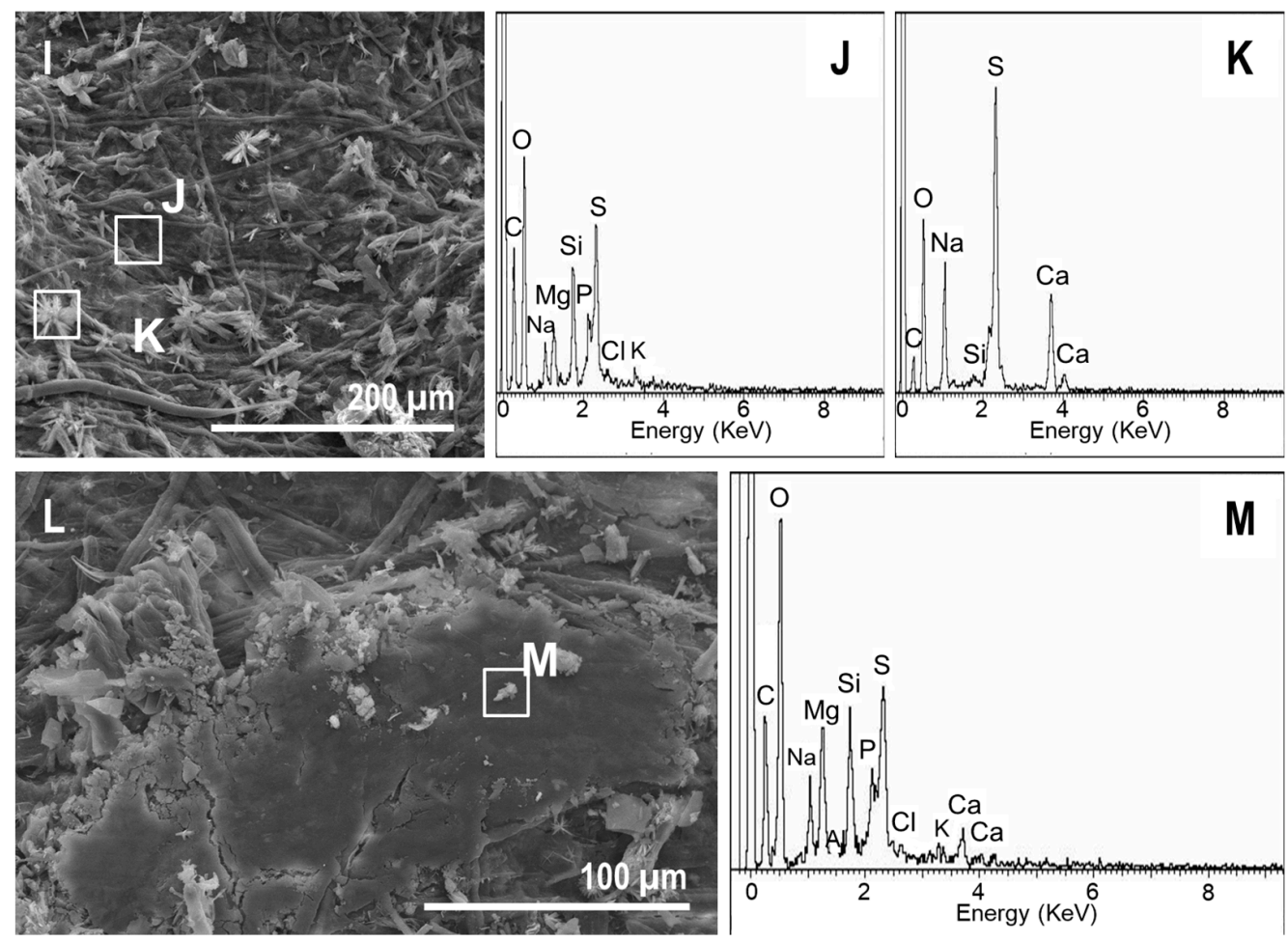

Figure 9. SEM-EDXS images of the precipitates on the upper side of the ferns in mats. (A) At day 7, the cyanobacterial filaments and diatoms as well as mineral precipitates were present. (B,C) EDXS spectra recorded at the areas highlighted in (A). (D,F) Precipitates that occurred over the mat in the impression left by the fern and their corresponding EDXS spectra of the spot highlighted in the image (E, G, and $\mathbf{H}$ respectively). (I,L) Precipitates over ferns in mats at day 60 and the corresponding EDXS spectra (J, K, and $\mathbf{M}$ respectively).
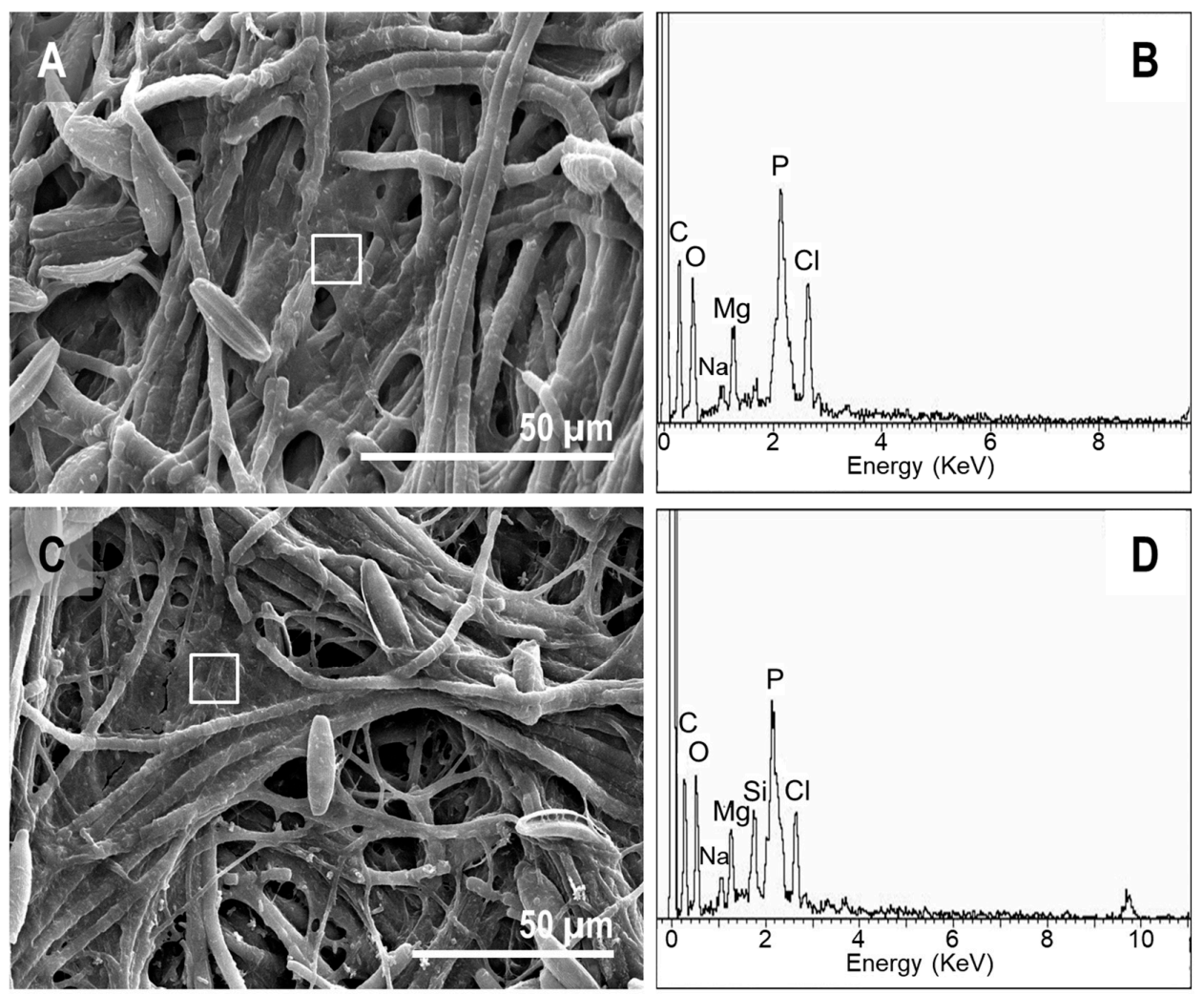

Figure 10. Cont. 

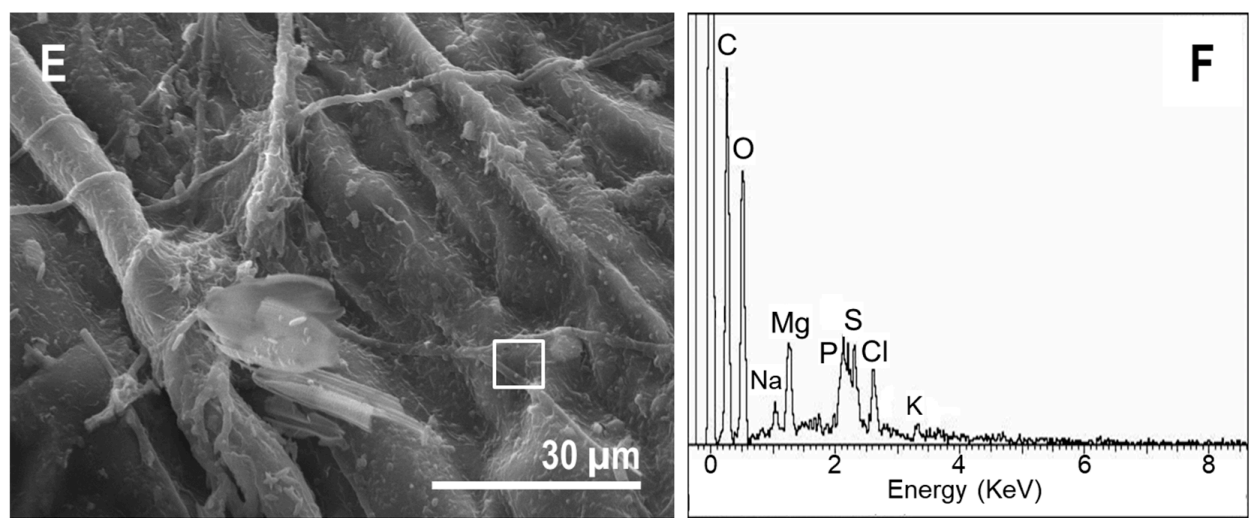

Figure 10. SEM-EDXS images of the microbial sarcophagus growing over ferns at day $30(\mathbf{A}, \mathbf{C})$ and at day $60(\mathbf{E})$. (B,D,F) correspond to the EDXS spectra of the sites highlighted in $(\mathbf{A}, \mathbf{C}, \mathbf{E})$ respectively.

\section{Discussion}

The delayed decay sequence in the presence of mats is consistent with previous experiments with plants [35], as well as with the results of experiments on the role of microbial mats in animal decay [14,31], but the effect size was much smaller. This is likely due to the plant composition. For instance, the cuticle of the adaxial side of the pinna is rich in cutin polymers and other waxes [62], which are known to be very recalcitrant components. In fact, Mösle et al. [63] proposed that differences in preservation between different plant taxa can be explained by the presence of these kinds of recalcitrant compounds in the tissue. In addition, fern pinna are rich in tannins, i.e., vegetable polyphenols with antimicrobial properties [64]. The presence of these compounds can also explain the slow decay of the controls during the experiment. Furthermore, an important aspect of soft tissue preservation is mineralization [65], and in this experiment, the presence of precipitates on both sides of fronds occurred either in mats or in controls. Control precipitates that were produced at low $\mathrm{pH}$ levels were related to the formation of fungal biofilm, whereas those that were influenced by mats occurred at high $\mathrm{pH}$ values. However, although the decay sequence in the controls and mats was equivalent, and their patterns of decay were much alike, the presence of microbial mats contributed to the integrity of the ferns' inner tissues.

Decay affected pinna in both conditions (controls and microbial mats, Figure 11). Confirming previous observations [47], we detected a differential decay of tissues in both processes. The mesophyll and the lower epidermis were more quickly affected by decay, while the upper epidermis remained undamaged for longer. This latter tissue is covered by the cuticle, which is a protective layer that is composed of insoluble biopolyester that is resistant to degradation [66]. The higher frailty that was observed in the lower epidermis could be due to the presence of stomata, where the protection of the cuticle is lost. The vascular bundle within the mesophyll deteriorated slowly. However, the fern pinnae in the control group were subjected to mechanical cracking and fungal invasion. The cuticle can be damaged by mechanical cracking [46], which would facilitate the entry of degradative agents such as the fungal filaments that were observed in our experiment at day 60 in the controls. Thus, in general, pinnae in sediment showed a greater extent of decomposition, which was also influenced by the lower $\mathrm{pH}$ during the first few months, and also promoted the damage of cuticles. In addition to $\mathrm{pH}$, the alteration of the mesophyll was probably due to the entry of microorganisms. The endodermis, despite being lignified, and the vascular bundles also suffered from degradation. It is interesting to note that the microorganisms that were detected inside the control pinna were fungi, because they are implicated in the degradation of the vegetable matter, especially lignin [67]. Filamentous fungi were absent in the fronds that were placed over mats. We also noticed the presence of precipitates in the inner structures of the controls. The mechanical cracking of the cuticle not only allowed microorganisms to penetrate, it also allowed the penetration of water, which generated precipitate deposits in the inner spaces of the tissue controls. In general, these precipitates were composed of calcium and sulfate. 
This was likely the result of the water column's composition, which had high concentrations of these two ions (Table 1).
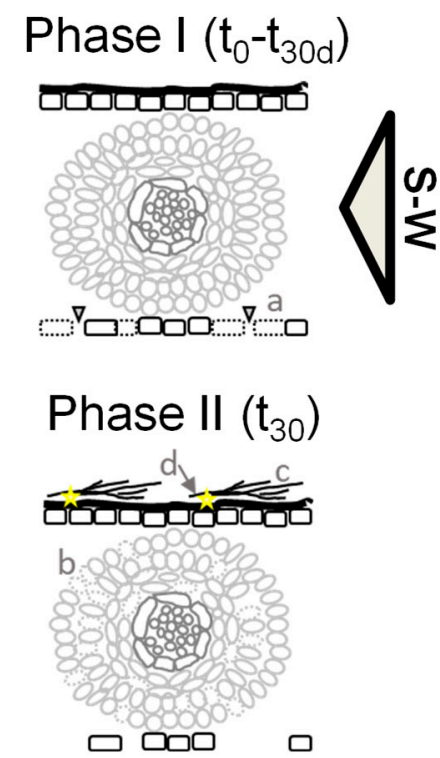

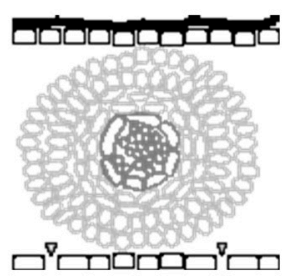

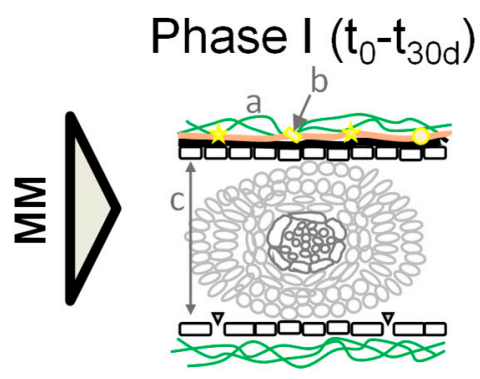

Phase II $\left(t_{>30 d}\right)$

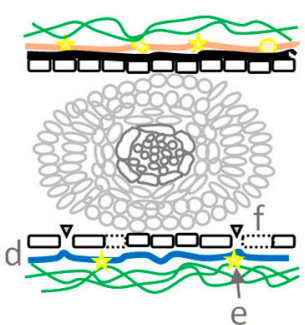

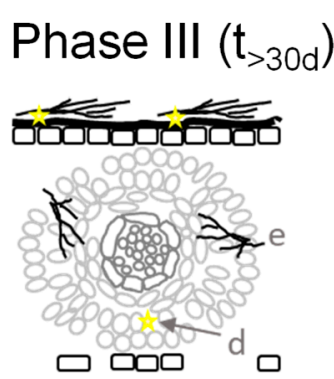

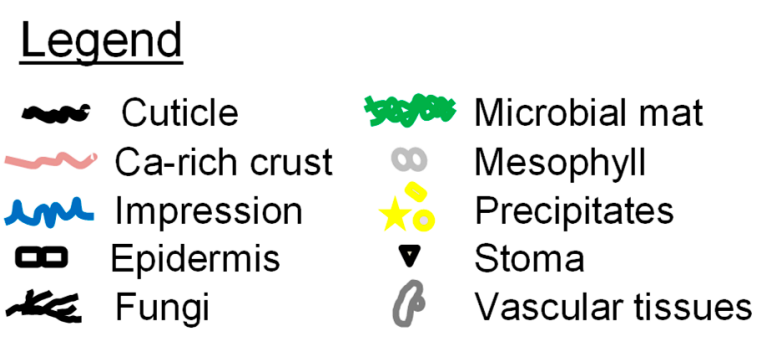

Figure 11. Schema of the taphonomic alterations observed in the control (sediment-water, S-W) and microbial mat (MM) tanks. S-W alterations observed at the sediment-water interface (control tanks). Phase (1): a, breakage of lower epidermis cells with stoma. Phase (2): b, fungal external invasion; c, mesophyll cell disorganization and deformation; $d$, mineral precipitation. Phase (3): e, fungal inner invasion at the endodermis; $\mathrm{f}$, mineral precipitation in the inner tissues. $\mathrm{MM}$, alterations observed in subaqueous conditions with microbial mats. Phase (1): a, mesophyll compression; $b$, mat coverage of the rest and early precipitation of a veil enriched in calcium; $c$, early mineral precipitation in the upper epidermis. Phase (2): $d$, generation of pinnule impressions; e, mineral precipitation at the lower epidermis; $f$, breakage of lower epidermis cells with stoma.

The growth of a microbial cover over the fronds in mats prevents the development of fungal masses. The mat cover also acts as protective device that prevents potential epidermal ruptures. Under light conditions, chlorophyll suffers photodegradation [68,69], but this was not detected in fronds over mats, in which the modification of color occurred more slowly than in the controls, even though they were kept in the dark during the experiment. However, these differences in color and the darkening of fragments over time can be explained by two parallel processes. First, the degradation of chlorophyll in controls can be related to the lower $\mathrm{pH}$, which induces the faster decay of pigments such as chlorophyll [70]. Second, the mat created a dense matrix that is rich in extracellular polymeric substances (EPS) [71-73]. EPS are made by a large variety of monosaccharides and polysaccharides as well as proteins [60] that can trap protons and modify the penetration of light [74]. Consequently, this EPS matrix that covered the samples from the very beginning acted as protection against light, among other dangers. 
The precipitates on the fronds that were placed over microbial mats were abundant, which is consistent with previous hypotheses and experiments with simple biofilms [35,48,75]. Differences in abundance between controls and mats might be explained by the influence of microbial mats in mineral precipitation [76,77], and the potential action of EPS as a nucleation factor for precipitates to occur [78]. This association between mats and the mineralization of biological rests has support from animal experiments [14,33]. These precipitates might also act as a protective cover, and in such cases, the massive mineralization that is observed beneath the plant (i.e., in the contact zone between the lower side of the plant and the microbial mat) might be relevant to the generation of a negative impression after a few days (detected at day 7). This kind of generation of a negative impression is consistent with previous experiments using animals [34]. Most of the precipitates that were found in both mat and control tanks were formed by $\mathrm{Ca}$ and S. Taking into account the relative proportions and compositions, these precipitates were compatible with the formation of gypsum. Gypsum has already been observed in several deposits with plant fossils (i.e., Wing; Chaney and DiMichele or Sun et al. [79-81]), but it is rare to find vegetable fossils that were formed totally or partially by this mineral. However, there are several examples of plant preservation in gypsum such as wood remains from the Upper Cretaceous in Lo Hueco (Cuenca, Spain) [82]. Moreover, sulfur can form pirite $\left(\mathrm{FeS}_{2}\right)$ in the presence of iron, which is more commonly found in permineralized fossil leaves [83]. Apart from gypsum and the possibility of pyrite, precipitates in fronds in mats also contained $\mathrm{Mg}, \mathrm{Na}, \mathrm{Cl}$, and occasionally, $\mathrm{Si}, \mathrm{K}$, or P, and their morphologies (e.g., starred, spherical, conglomerates, or rod-shaped precipitates) were much more varied than the precipitates that were observed in the controls. Some of these morphologies (i.e., starred) are similar to the ones that were observed in precipitates formed on fossil material from Las Hoyas (Lower Cretaceous of Cuenca, Spain), for example (Figure 12A), where they can be found together with fungi hyphae. It must be noted that silica permineralizations and petrifications are very frequent in fossil records, where internal anatomical characters are extremely well-preserved (e.g., Moreau et al. or Xu et al. [84,85]).
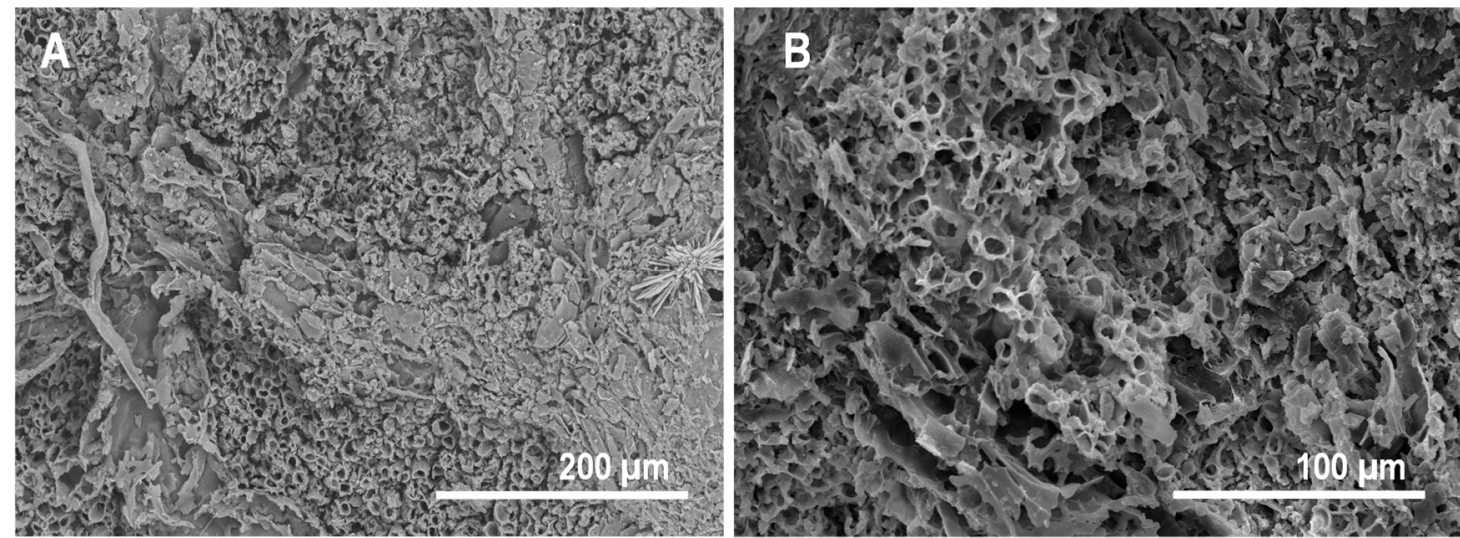

Figure 12. SEM images of the fossil fern Weichselia reticulata (Stokes et Webb) Fontaine from Las Hoyas (Lower Cretaceous of Cuenca, Spain). (A) Starred precipitates and fungi-like filaments over the fossil. (B) Exceptionally well-preserved internal tissue. Sometimes, the material is charcoalified, showing the exposure to high temperatures during fossilization.

This study of microbial mats is a complementary contribution to previous models of plant decomposition mediated by biofilms [35]. This type of experiment is crucial to improve the understanding of fossilization, and we observed that although plant remains are quite resistant to decay, microbial mats play a role in enhancing the preservation of fern pinnae. Taking the high diversity and fern abundance of the Devonian and Cretaceous floras into consideration, as well as the continuous presence of ferns in the fossil records [86], the experiments that were performed here are key to shedding light on the fossilization process in floras of different ages, even before the radiation of angiosperms. Fossil leaves can be preserved as compressions (compressed plant 
material preserved as a thin carbonaceous layer, generally including the cuticle), as coal and charcoal, as impressions (negative imprints of the plant parts where the biological material has disintegrated), as permineralizations (where minerals fill the cell lumen and intercellular spaces, but do not replace the cell walls completely, e.g., silica, iron oxide, or limonite), as petrifications (where all of the original organic matter in the plant has been replaced by minerals), or as mummifications (where the plant material is unaltered) $[41,86]$. These types of preservation provide variable degrees of quality in the external and internal structures of the fossil leaves $[41,47,66]$. The relevance of external impressions in fossil plants is undebated [87], since they give reliable information about the surface of plant parts. Internal preservation is best observed in permineralizations, petrifications, and mummifications [86], but exceptionally, it can also be observed in the carbonaceous layer of compressions, generally those preserving the cuticle, and in charcoalified material that has not been burnt at high temperatures. One example of this is the exceptionally well-preserved internal structures of charcoalified specimens (Figure 12A,B) from the Lower Cretaceous of Las Hoyas (Cuenca, Spain), where microbial mats were present [3].

In our experimental results, the pinnae surface formed a clear impression on the microbial mats, indicating that this type of plant preservation is not only produced on the sediment or on clays mediated by biofilms [35], but could also occur in sediments with mats. Further, the inner preservation seems to depend on the integrity of the cuticle; the formation of the microbial sarcophagus on the pinnae would be essential to avoid breakage and hydrolysis. However, we detected a differentiated decay of plant tissues related to tissue composition, which constitutes a bias. This tissue bias has already been observed in fossil plants from different groups. For instance, a dorsoventral gradient in the decay through leaf sections occurred in the mummified fossils of the taxodiaceous conifer Metasequoia Hu and Cheng found at the Buchanan Lake Formation (Eocene, Canada) [88]. This gradient of preservation was also observed in other plant fossils, such as the exceptionally well-preserved specimens from Charente-Maritime (Cenomanian, western France); while several tissues, such as the stomatal crypts, were undamaged, and fossilized, spongy parenchyma was only partially conserved [84,89]. In addition, based on these results, the present model of preservation in mats unifies the two categories for the exceptional preservation of plant fossils [41]. Transport processes and decay-diagenesis have been assumed to produce different fossils, i.e., fossils preserving the entire and original arrangement and fossils with cellular detail, respectively. However, the formation of the mat sarcophagus can likely explain both the articulation of fossils and the inner tissue preservation.

\section{Conclusions}

This taphonomic experiment provided evidence of the substantial factors influencing plant preservation that have been tested in laboratory conditions. Fern pinnules are formed of more labile tissues than other plant parts such as woody fragments, cones, or seeds. Pinnule decay was shown to last much longer than four months, because they were perfectly identifiable and not yet matured as organic debris at the end of the experiment. The results show that plant preservation might equally succeed at the sediment-water interface (control tanks) and in subaqueous environments with rapid entombment by microbial mats, although with differential levels of tissue preservations. In the control tanks, ferns decayed at the sediment-water interface. The suboxic zone (in the sediment water interphase) and fluctuating redox conditions promoted fungal and bacterial activity, and those tissues that were composed of resistant macromolecules (cuticles and vascular bundles) were less or least damaged. The promotion of fungal-bacterial biofilms that succeeded under anoxia and near neutral $\mathrm{pH}$ conditions prompted external and internal mechanical and geochemical changes of the fern pinnae. The mineralized-inner and outer-precipitations that were related to the chemical composition of the water were infrequent in control tanks.

The experiment also characterized a new type of plant part preservation in a subaqueous continental environment [90] that was concretely produced in the presence of microbial mats. Plants became trapped and progressively buried by the mat community that prevents fungal invasion, 
mechanical cracking, and inner tissue breakages with drastic alterations. In mat tanks, the setting conditions were characterized as having stable DO, and with a basic $\mathrm{pH}$. Such settings, together with the molecular composition of the mats (made up of EPS substances), would have promoted the integrity of the external and internal tissues, and would have favored a massive and diverse mineralization, confirming previous outcomes of experiments with plants. These actuotaphonomic experiences enable the sequence of decay occurring within distinct environmental settings to be modeled and demonstrate the fossilization patterns in fossil plants.

Author Contributions: Conceptualization: A.I.L.-A., A.D.B. and M.C.G.; Methodology: A.I.L.-A., A.D.B., M.I. and M.C.G.; Software: A.V., C.B.-M. and M.I.; Validation: A.D.B., M.I., M.C.G. and A.I.L.-A.; Formal Analysis: A.V., M.I. and A.I.L.-A.; Investigation: A.V., C.B.-M., M.I. and A.I.L.-A.; Resources: M.C.G. and A.I.L.-A.; Data Curation: A.V. and M.I.; Writing-Original Draft Preparation: M.I. and A.I.L.-A.; Writing-Review \& Editing: A.D.B. and C.B.-M.; Visualization: A.V. and A.I.L.-A.; Supervision: M.C.G., A.I.L.-A. and A.D.B.; Project Administration: A.I.L.-A. and A.D.B.; Funding Acquisition: A.I.L.-A. and A.D.B.

Funding: This work is part of the research project CGL2013-42643-P funded by the Spanish Ministry of Science, Innovation and Universities (former Ministry of Economy and Competitiveness). The grant supporting C. Blanco-Moreno was funded by the Universidad Autónoma de Madrid.

Acknowledgments: This work, which is part of the research projects CGL2013-42643-P was funded by the Spanish Ministry of Science, Innovation and Universities (former Ministry of Economy and Competitiveness). The FPI-UAM research grant supporting C. Blanco-Moreno was funded by the Universidad Autónoma de Madrid. SEM observation was conducted at SIdI UAM (Madrid) and we thank Esperanza Salvador, Isidoro Poveda and Enrique Rodríguez Cañas for the help. We also thank Antonio Romero for the help using the rotary microtome.

Conflicts of Interest: The authors declare no conflict of interest.

\section{References}

1. Fernández-López, S.R. La Material Fósil. Una Concepción Dinamicista de los Fósiles. In Nuevas Tendencias en Paleontología; Aguirre, E., Ed.; Consejo Superior de Investigaciones Científicas: Madrid, Spain, 1989; pp. 25-45. (In Spanish)

2. Seilacher, A. Begriff und bedeutung der Fossil-Lagerstätten. Neues Jarhb. für Geol. und Paläontologie 1970, 1, 34-39. (In German)

3. Buscalioni, Á.D.; Fregenal-Martínez, M.A. A holistic approach to the palaeoecology of Las Hoyas Konservat-Lagerstätte (La Huérguina Formation, Lower Cretaceous, Iberian Ranges, Spain). J. Iber. Geol. 2010, 36, 297-326. [CrossRef]

4. Schweitzer, M.H.; Suo, Z.; Avci, R.; Asara, J.M.; Allen, M.A.; Arce, F.T.; Horner, J.R. Analyses of soft tissue from Tyrannosaurus rex suggest the presence of protein. Science 2007, 316, 277-280. [CrossRef] [PubMed]

5. Asara, J.M.; Schweitzer, M.H.; Freimark, L.M.; Philips, M.; Cantley, L.C. Protein sequences from mastodon and Tyrannosaurus rex revealed by mass spectrometry. Science 2007, 31, 280-285. [CrossRef] [PubMed]

6. Schweitzer, M.H.; Zheng, W.; Organ, C.L.; Avci, R.; Suo, Z.; Freimark, L.M.; Lebleu, V.S.; Duncan, M.B.; Vander Heiden, M.G.; Neveu, J.M.; et al. Biomolecular characterization and protein sequences of the Campanian hadrosaur B. canadensis. Science 2009, 324, 626-631. [CrossRef] [PubMed]

7. McNamara, M.E.; Orr, P.J.; Kearns, S.L.; Alcalá, L.; Anadón, P.; Peñalver-Mollá, E. Soft-tissue preservation in Miocene frogs from Libros, Spain: Insights into the genesis of decay microenvironments. Palaios 2009, 24, 104-117. [CrossRef]

8. Navalón, G.; Marugán-Lobón, J.; Chiappe, L.M.; Luis Sanz, J.; Buscalioni, Á.D. Soft-tissue and dermal arrangement in the wing of an Early Cretaceous bird: Implications for the evolution of avian flight. Sci. Rep. 2015, 5, 14864. [CrossRef] [PubMed]

9. Vinther, J.; Briggs, D.E.G.; Prum, R.O.; Saranathan, V. The colour of fossil feathers. Biol. Lett. 2008, 4, 522-525. [CrossRef] [PubMed]

10. Briggs, D.E.G. Molecular taphonomy of animal and plant cuticles: Selective preservation and diagenesis. Philos. Trans. R. Soc. B Biol. Sci. 1999, 354, 7-17. [CrossRef]

11. Gueriau, P.; Bertrand, L. Deciphering exceptional preservation of fossils through trace elemental imaging. Micros. Today 2015, 23, 20-25. [CrossRef] 
12. Davesne, D.; Gueriau, P.; Dutheil, D.B.; Bertrand, L. Exceptional preservation of a Cretaceous intestine provides a glimpse of the early ecological diversity of spiny-rayed fishes (Acanthomorpha, Teleostei). Sci. Rep. 2018, 8, 8509. [CrossRef] [PubMed]

13. Gueriau, P.; Jauvion, C.; Mocuta, C. Show me your yttrium, and I will tell you who you are: Implications for fossil imaging. Palaeontology 2018. [CrossRef]

14. Iniesto, M.; Villalba, I.; Buscalioni, A.D.; Guerrero, M.C.; López-Archilla, A.I. The effect of microbial mats in the decay of anurans with implications for understanding taphonomic processes in the fossil record. Sci. Rep. 2017, 7, 45160. [CrossRef] [PubMed]

15. Raff, E.C.; Villinski, J.; Turner, F.R.; Donoghue, P.C.J.; Raff, R.A. Experimental taphonomy shows the feasibility of fossil embryos. Proc. Natl. Acad. Sci. USA 2006, 103, 5846-5851. [CrossRef] [PubMed]

16. Raff, E.C.; Schollaert, K.L.; Nelson, D.E.; Donoghue, P.C.J.; Thomas, C.-W.; Turner, F.R.; Stein, B.D.; Dong, X.; Bengtson, S.; Huldtgren, T.; et al. Embryo fossilization is a biological process mediated by microbial biofilms. Proc. Natl. Acad. Sci. USA 2008, 105, 19360-19365. [CrossRef] [PubMed]

17. Butler, A.D.; Cunningham, J.A.; Budd, G.E.; Donoghue, P.C.J. Experimental taphonomy of Artemia reveals the role of endogenous microbes in mediating decay and fossilization. Proc. Biol. Sci. 2015, 282, 20150476. [CrossRef] [PubMed]

18. Briggs, D.E.G.; Kear, A.J. Fossilization of soft tissue in the laboratory. Science 1993, 259, 1439-1442. [CrossRef] [PubMed]

19. Hof, C.H.J.; Briggs, D.E.G. Decay and mineralization of mantis shrimps (Stomatopoda; Crustacea); a key to their fossil record. Palaios 1997, 12, 420-438. [CrossRef]

20. Sansom, R.S.; Gabbott, S.E.; Purnell, M.A. Non-random decay of chordate characters causes bias in fossil interpretation. Nature 2010, 463, 797-800. [CrossRef] [PubMed]

21. Sansom, R.S. Preservation and phylogeny of Cambrian ecdysozoans tested by experimental decay of Priapulus. Sci. Rep. 2016, 6, 32817. [CrossRef] [PubMed]

22. Wilson, P.; Parry, L.A.; Vinther, J.; Edgecombe, G.D. Unveiling biases in soft-tissue phosphatization: Extensive preservation of musculature in the cretaceous (cenomanian) polychaete Rollinschaeta myoplena (annelida: Amphinomidae). Palaeontology 2016, 59, 463-479. [CrossRef]

23. Gupta, N.S.; Michels, R.; Briggs, D.E.G.; Collinson, M.E.; Evershed, R.P.; Pancost, R.D. Experimental evidence for the formation of geomacromolecules from plant leaf lipids. Org. Geochem. 2007, 38, 28-36. [CrossRef]

24. Gupta, N.S.; Cambra-Moo, Ó.; Briggs, D.E.G.; Love, G.D.; Fregenal-Martínez, M.A.; Summons, R.E. Molecular taphonomy of macrofossils from the Cretaceous Las Hoyas Formation, Spain. Cretac. Res. 2008, 29, 1-8. [CrossRef]

25. Gupta, N.S.; Michels, R.; Briggs, D.E.G.; Evershed, R.P.; Pancost, R.D. The organic preservation of fossil arthropods: An experimental study. Proc. Biol. Sci. 2006, 273, 2777-2783. [CrossRef] [PubMed]

26. Gupta, N.S. Chitin: Formation and Diagenesis; Gupta, N.S., Ed.; Springer: Houten, The Netherlands, 2011; ISBN 978-90-481-9683-8.

27. Bernard, S.; Beyssac, O.; Benzerara, K.; Findling, N.; Tzvetkov, G.; Brown, G.E. XANES, Raman and XRD study of anthracene-based cokes and saccharose-based chars submitted to high-temperature pyrolysis. Carbon N. Y. 2010, 48, 2506-2516. [CrossRef]

28. Bernard, S.; Benzerara, K.; Beyssac, O.; Balan, E.; Brown, G.E., Jr. Evolution of the macromolecular structure of sporopollenin during thermal degradation as documented by infrared, Raman and C-XANES spectroscopies. Heliyon 2015, 1, e00034. [CrossRef] [PubMed]

29. Martin, D.; Briggs, D.E.G.; Parkes, R.J. Decay and mineralization of invertebrate eggs. Palaios 2005, 20, 562-572. [CrossRef]

30. Raff, E.C.; Andrews, M.E.; Turner, F.R.; Toh, E.; Nelson, D.E.; Raff, R.A. Contingent interactions among biofilm-forming bacteria determine preservation or decay in the first steps toward fossilization of marine embryos. Evol. Dev. 2013, 15, 243-256. [CrossRef] [PubMed]

31. Iniesto, M.; López-Archilla, A.I.; Fregenal-Martínez, M.A.; Buscalioni, Á.D.; Guerrero, M.C. Involvement of Microbial Mats In Delayed Decay: An Experimental Essay On Fish Preservation. Palaios 2013, 28, 56-66. [CrossRef]

32. Iniesto, M.; Laguna, C.; Florín, M.; Guerrero, M.C.; Chicote, Á.; Buscalioni, Á.D.; López-Archilla, A.I. The impact of microbial mats and their microenvironmental conditions in early decay of fish. Palaios 2015, 30, 792-801. [CrossRef] 
33. Iniesto, M.; Zeyen, N.; López-Archilla, A.I.; Bernard, S.; Buscalioni, Á.D.; Guerrero, M.C.; Benzerara, K. Preservation in microbial mats: Mineralization by a talc-like phase of a fish embedded in a microbial sarcophagus. Front. Earth Sci. 2015, 3. [CrossRef]

34. Iniesto, M.; Buscalioni, Á.D.; Guerrero, M.C.; Benzerara, K.; Moreira, D.; López-Archilla, A.I. Involvement of microbial mats in early fossilization by decay delay and formation of impressions and replicas of vertebrates and invertebrates. Sci. Rep. 2016, 6, 1-12. [CrossRef] [PubMed]

35. Locatelli, E.R.; Mcmahon, S.; Bilger, H. Biofilms mediate the preservation of leaf adpression fossils by clays. Palaios 2017, 32, 708-724. [CrossRef]

36. Scott, A.C.; Rex, G. The formation and significance of carboniferous coal balls. Philos. Trans. R. Soc. Lond. B Biol. Sci. 1985, 311, 123-137. [CrossRef]

37. Phillips, T.L.; Peppers, R.A. Changing patterns of Pennsylvanian coal-swamp vegetation and implications of climatic control on coal occurrence. Int. J. Coal Geol. 1984, 3, 205-255. [CrossRef]

38. Scott, A. Preservation by fire. In Paleobiology II; Briggs, D.E., Crowther, P.R., Eds.; Blackwell Science Ltd.: Oxford, UK, 2001; pp. 277-280.

39. Scott, A. Charcoal recognition, taphonomy and uses in palaeoenvironmental analysis. Palaeogeogr. Palaeoclimatol. Palaeoecol. 2010, 291, 11-39. [CrossRef]

40. Jones, T.; Scott, A.; Cope, M. Reflectance measurements and the temperature of formation of modern charcoals and implications for studies of fusain. Bull. Soc. Géol. Fr. 1991, 162, 193-200.

41. Locatelli, E.R. The exceptional preservation of plant fossils: A review of taphonomic pathways and biases in the fossil record. Paleontol. Soc. Pap. 2014, 20, 237-258. [CrossRef]

42. Newman, S.A.; Mariotti, G.; Pruss, S.; Bosak, T. Insights into cyanobacterial fossilization in Ediacaran siliciclastic environments. Geology 2016, 44, 579-582. [CrossRef]

43. Gehling, J.G. Microbial mats in terminal proterozoic siliciclastics: Ediacaran death masks. Palaios 1999, 14, 40. [CrossRef]

44. Briggs, D.G.E.; Kear, A.J. Decay and mineralization of shrimps. Palaios 1994, 9, 431-456. [CrossRef]

45. Sagemann, J.; Bale, S.J.; Briggs, D.E.G.; Parkes, R.J. Controls on the formation of authigenic minerals in association with decaying organic matter: An experimental approach. Geochim. Cosmochim. Acta 1999, 63, 1083-1095. [CrossRef]

46. Gupta, N.S.; Pancost, R.D. Biomolecular and physical taphonomy of angiosperm leaf during early decay: Implications for fossilization. Palaios 2004, 19, 428-440. [CrossRef]

47. Locatelli, E.R. The Roles of Decay and Mineralization in Leaf Preservation: IMPLICATIONS for the Fossil Record. Ph.D. Thesis, Yale University, New Haven, CT, USA, 2016.

48. Dunn, K.A.; McLean, R.J.C.; Upchurch Jr, G.R.; Folk, R.L. Enhancement of leaf fossilization potential by bacterial biofilms. Geology 1997, 25, 1119-1122. [CrossRef]

49. Cohen, Y.; Rosenberg, E. Microbial Mats: Physiological Ecology of Benthic Microbial Communities; American Society for Microbiology: Washington, DC, USA, 1989.

50. Stolz, J.F. Structure of Microbial Mats and Biofilms. In Microbial Sediments; Riding, R.E., Awramik, S.M., Eds.; Springer: Berlin/Heidelberg, Germany, 2000; pp. 1-8, ISBN 978-3-642-08275-7.

51. Seilacher, A.; Reif, W.-E.; Westphal, F.; Riding, R.; Clarkson, E.N.K.; Whittington, H.B. Sedimentological, ecological and temporal patterns of fossil Lagerstatten [and Discussion]. Philos. Trans. R. Soc. B Biol. Sci. 1985, 311, 5-24. [CrossRef]

52. Gall, J.-C.; Bernier, P.; Gaillard, C.; Barale, G.; Bourseau, J.-P.; Buffetaut, E.; Wenz, S.; Millot, G. Influence du développement d'un voile algaire sur la sédimentation et la taphonomie des calcaires lithographiques. Exemple du gisement de Cerin (Kimmeridgien supérieur, Jura méridional français). Comptes Rendus l'Académie Sci. Paris 1985, 301, 547-551. (In French)

53. Briggs, D.E.G. The role of biofilms in the fossilization of non-biomineralized tissues. In Fossil and Recent Biofilms: A Natural History of Life on Earth; Krumbein, W.E., Paterson, D.M., Zavarzin, G.A., Eds.; Springer: Dordrecht, The Netherlands, 2003; pp. 281-290, ISBN 978-90-481-6412-7.

54. Tomescu, A.M.F.; Klymiuk, A.A.; Matsunaga, K.K.S.; Bippus, A.C.; Shelton, G.W.K. Chapter 3-Microbes and the fossil record: Selected topics in paleomicrobiology. In Advances in Environmental Microbiology. Their World: A Diversity of Microbial Environments; Hurst, C.J., Ed.; Springer International Publishing: Cham Switzerland, 2016; pp. 69-169, ISBN 978-3-319-28069-1. 
55. Marty, D.; Strasser, A.; Meyer, C.A. Formation and taphonomy of human footprints in microbial mats of present-day tidal-flat environments: Implications for the study of fossil footprints. Ichnos 2009, 16, 127-142. [CrossRef]

56. Shute, C.; Cleal, C. Paleobotany in museums. Geol. Curator 1986, 4, 553-559.

57. Cleal, C.J.; Thomas, B.A. Botanical nomenclature and plant fossils. Taxon 2010, 59, 261-268.

58. Guerrero, M.C.; Balsa, J.; Pascual, M.; Martínez, B.; Montes, C. Caracterización limnológica de la laguna Salada de Chiprana (Zaragoza, España) y sus comunidades de bacterias fototróficas. Limnetica 1991, 7, 83-96. (In Spanish)

59. Stal, L.J. Physiological ecology of cyanobacteria in microbial mats and other communities. New Phytol. 1995, 131, 1-32. [CrossRef]

60. Stal, L. Cyanobacterial mats and stromatolites. In The Ecology of Cyanobacteria; Whittington, H., Potts, M., Eds.; Springer: Dordrecht, The Netherlands, 2000; pp. 61-120.

61. Reihman, M.A.; Schabilion, J.T. Cuticles of two species of Alethopteris. Am. J. Bot. 1976, 63, 1039. [CrossRef]

62. Kunst, L.; Samuels, A.L. Biosynthesis and secretion of plant cuticular wax. Prog. Lipid Res. 2003, 42, 51-80. [CrossRef]

63. Mösle, B.; Collinson, M.E.; Finch, P.; Stankiewicz, B.A.; Scott, A.; Wilson, R. Factors infuencing the preservation of plant cuticles: A comparison of morphology and chemical composition of modern and fossil examples. Org. Geochem. 1998, 29, 1369-1380. [CrossRef]

64. Ashok, P.K.; Upadhyaya, K. Tannins are astringent. J. Pharmacogn. Phytochem. 2012, 1, 45-50.

65. Purnell, M.A.; Donoghue, P.J.C.; Gabbott, S.E.; McNamara, M.E.; Murdock, D.J.E.; Sansom, R.S. Experimental analysis of soft-tissue fossilization: Opening the black box. Palaeontology 2018, 61, 317-323. [CrossRef]

66. Collinson, M. Chapter 6. Molecular Taphonomy of plant organic skeletons. In Taphonomy: Process and Bias though Time, Topics in Geobiology 32; Allison, A., Bottjer, D., Eds.; Springer Science \& Business Media: Berlin/Heidelberg, Germany, 2011.

67. Tuomela, M.; Vikman, M.; Hatakka, A.; Itävaara, M. Biodegradation of lignin in a compost environment: A review. Bioresour. Technol. 2000, 72, 169-183. [CrossRef]

68. Streit, N.M.; Canterle, L.P.; do Canto, M.W.; Hecktheuer, L.H.H. The Chlorophylls (As clorofilas). Ciência Rural 2005, 35, 748-755. [CrossRef]

69. Hendry, G.; Price, A. Stress indicators: Chlorophylls and carotenoids. In Methods in Comparative Plant Ecology; Hendry, G., Grime, J., Eds.; Chapman \& Hall: London, UK, 1993; pp. 148-152.

70. Ryan-Stoneham, T.; Tong, C.H. Degradation kinetics of chlorophyll in peas as a function of pH. J. Food Sci. 2000, 65, 1296-1302. [CrossRef]

71. Flemming, H.-C.; Neu, T.R.; Wozniak, D.J. The EPS Matrix: The “House of Biofilm Cells”. J. Bacteriol. 2007, 189, 7945-7947. [CrossRef] [PubMed]

72. Flemming, H.-C.; Wingender, J. The biofilm matrix. Nat. Rev. Microbiol. 2010, 8, 623-633. [CrossRef] [PubMed]

73. Flemming, H.-C.; Wingender, J.; Szewzyk, U.; Steinberg, P.; Rice, S.A.; Kjelleberg, S. Biofilms: An emergent form of bacterial life. Nat. Rev. Microbiol. 2016, 14, 563-575. [CrossRef] [PubMed]

74. Decho, A.W.; Gutierrez, T. Microbial Extracellular Polymeric Substances (EPSs) in Ocean Systems. Front. Microbiol. 2017, 8, 922. [CrossRef] [PubMed]

75. Spicer, R.A. The pre-depositional formation of some leaf impressions. Palaeontology 1978, 20, 907-912.

76. Reid, R.P.; Visscher, P.T.; Decho, A.W.; Stolz, J.F.; Bebout, B.M.; Dupraz, C.; Macintyre, I.G.; Paerl, H.W.; Pinckney, J.L.; Prufert-Bebout, L.; et al. The role of microbes in accretion, lamination and early lithificationof modern marine stromatolites. Nature 2000, 406, 989-992. [CrossRef] [PubMed]

77. Decho, A.W.; Kawaguchi, T. Extracellular Polymers (EPS) and calcification within modern marine stromatolites. In Fossil and Recent Biofilms: A Natural History of Life on Earth; Springer Science \& Business Media: Berlin/Heidelberg, Germany, 2003; pp. 227-240.

78. Dupraz, C.; Reid, R.P.; Braissant, O.; Decho, A.W.; Norman, R.S.; Visscher, P.T. Processes of carbonate precipitation in modern microbial mats. Earth-Sci. Rev. 2009, 96, 141-162. [CrossRef]

79. Wing, S. Fossil flora and plant bearing beds of the central Bighorn Basin. In Early Cenozoic Paleontology and Stratigraphy of the Bighorn Basin, Wyoming; Gingerich, P.D., Ed.; The Palaeontological Association: Durham, UK, 1980. 
80. Chaney, D.; DiMichele, W. Paleobotany of the classic redbeds (Clear Fork Group, Early Permian) of north central Texas. In Proceedings of the XVth International Congress on Carboniferous and Permian Stratigraphy, Utrecht, The Netherlands, 10-16 August 2003; Volume 1, pp. 357-366.

81. Sun, B.; Dai, J.; Wang, Y.; Jia, H.; Yan, D.; Jiang, Z. Pseudofrenelopsis fossils from Cretaceous gypsum beds in Guixi, Jiangxi Province, China and their geological significance. Isl. Arc 2011, 20, 43-56. [CrossRef]

82. Cambra-Moo, O.; Barroso-Barcenilla, F.; Berreteaga, A.; Carenas, B.; Coruña, F.; Domingo, L.; Domingo, M.S.; Elvira, A.; Escaso, F.; Ortega, F.; et al. Preliminary taphonomic approach to "Lo Hueco" palaeontological site (Upper Cretaceous, Cuenca, Spain). Geobios 2012, 45, 157-166. [CrossRef]

83. Martín-Closas, C.; Gomez, B. Taphonomie des plantes et interprétations paléoécologiques. Une synthèse. Geobios 2004, 37, 65-88. [CrossRef]

84. Moreau, J.-D.; Néraudeau, D.; Tafforeau, P.; Dépré, É. Study of the histology of leafy axes and male cones of Glenrosa carentonensis sp. nov. (Cenomanian Flints of Charente-Maritime, France) using synchrotron microtomography linked with palaeoecology. PLoS ONE 2015, 10, e0134515. [CrossRef] [PubMed]

85. Xu, H.-H.; Berry, C.M.; Stein, W.E.; Wang, Y.; Tang, P.; Fu, Q. Unique growth strategy in the Earth's first trees revealed in silicified fossil trunks from China. Proc. Natl. Acad. Sci. USA 2017, 114, 12009-12014. [CrossRef] [PubMed]

86. Taylor, T.N.; Taylor, E.L.; Krings, M. Paleobotany: The Biology and Evolution of Fossil Plants; Taylor, T.N., Ed.; Academic Press: Cambridge, MA, USA, 2009; ISBN 9780123739728.

87. Walton, J. On a new method of investigating fossil plant impressions or incrustations. Ann. Bot. 1923, 37, 379-391. [CrossRef]

88. Schoenhut, K.; Vann, D.R.; LePage, B.A. Cytological and ultrastructural preservation in Eocene Metasequoia leaves from the Canadian High Arctic. Am. J. Bot. 2004, 91, 816-824. [CrossRef] [PubMed]

89. Moreau, J.-D.; Néraudeau, D.; Perrichot, V.; Tafforeau, P. 100-million-year-old conifer tissues from the mid-Cretaceous amber of Charente (western France) revealed by synchrotron microtomography. Ann. Bot. 2017, 119, 117-128. [CrossRef] [PubMed]

90. Gastaldo, R.A.; Demko, T.M. The relationship between continental landscape evolution and the plant-fossil record: Long term hydrologic controls and preservation. In Taphonomy. Aims \& Scope Topics in Geobiology Book Series; Allison, P.A., Bottjer, D.J., Eds.; Springer: Dordrecht, The Netherlands, 2011; Volume 32, pp. 249-285, ISBN 978-90-481-8642-6.

(C) 2018 by the authors. Licensee MDPI, Basel, Switzerland. This article is an open access article distributed under the terms and conditions of the Creative Commons Attribution (CC BY) license (http:/ / creativecommons.org/licenses/by/4.0/). 